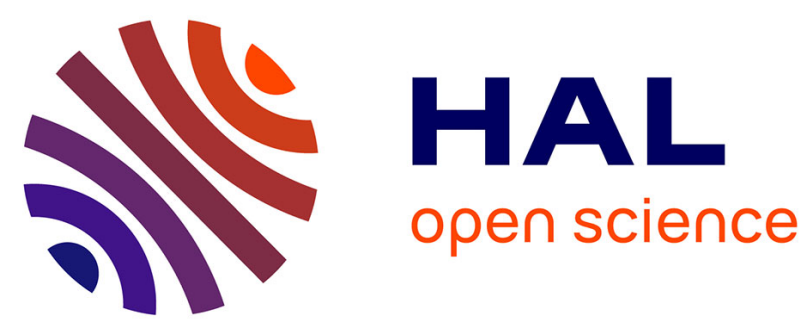

\title{
Structural heritage, reactivation and distribution of fault and fracture network in a rifting context: Case study of the western shoulder of the Upper Rhine Graben
}

\author{
Lionel Bertrand, Jessie Jusseaume, Yves Géraud, Marc Diraison, \\ Pierre-Clément Damy, Vivien Navelot, Sébastien Haffen
}

\section{To cite this version:}

Lionel Bertrand, Jessie Jusseaume, Yves Géraud, Marc Diraison, Pierre-Clément Damy, et al.. Structural heritage, reactivation and distribution of fault and fracture network in a rifting context: Case study of the western shoulder of the Upper Rhine Graben. Journal of Structural Geology, 2018, 108, pp.243-255. 10.1016/j.jsg.2017.09.006 . hal-02457294

\section{HAL Id: hal-02457294 \\ https://hal.univ-lorraine.fr/hal-02457294}

Submitted on 23 Jun 2020

HAL is a multi-disciplinary open access archive for the deposit and dissemination of scientific research documents, whether they are published or not. The documents may come from teaching and research institutions in France or abroad, or from public or private research centers.
L'archive ouverte pluridisciplinaire HAL, est destinée au dépôt et à la diffusion de documents scientifiques de niveau recherche, publiés ou non, émanant des établissements d'enseignement et de recherche français ou étrangers, des laboratoires publics ou privés.

\section{(1) (1) $\$$}

Distributed under a Creative Commons Attribution - NonCommercial - NoDerivatives 44.0 


\section{Accepted Manuscript}

Structural heritage, reactivation and distribution of fault and fracture network in a rifting context: Case study of the western shoulder of the Upper Rhine Graben

Lionel Bertrand, Jessie Jusseaume, Yves Géraud, Marc Diraison, Pierre-Clément Damy, Vivien Navelot, Sébastien Haffen

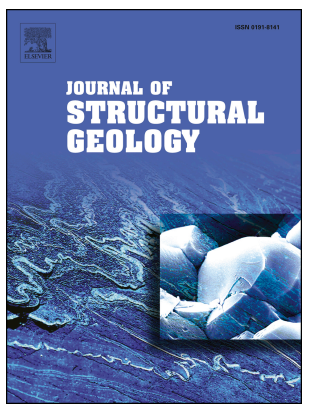

PII:

$$
\text { S0191-8141(17)30177-3 }
$$

DOI: 10.1016/j.jsg.2017.09.006

Reference: $\quad$ SG 3524

To appear in: Journal of Structural Geology

Received Date: 13 December 2016

Revised Date: 31 August 2017

Accepted Date: 3 September 2017

Please cite this article as: Bertrand, L., Jusseaume, J., Géraud, Y., Diraison, M., Damy, Pierre.-Clé., Navelot, V., Haffen, Sé., Structural heritage, reactivation and distribution of fault and fracture network in a rifting context: Case study of the western shoulder of the Upper Rhine Graben, Journal of Structural Geology (2017), doi: 10.1016/j.jsg.2017.09.006.

This is a PDF file of an unedited manuscript that has been accepted for publication. As a service to our customers we are providing this early version of the manuscript. The manuscript will undergo copyediting, typesetting, and review of the resulting proof before it is published in its final form. Please note that during the production process errors may be discovered which could affect the content, and all legal disclaimers that apply to the journal pertain. 


\section{Structural heritage, reactivation and distribution of fault and fracture network in a rifting context: case study of the western shoulder of the Upper Rhine Graben.}

Lionel Bertrand * a , Jessie Jusseaume ${ }^{\text {a }}$, Yves Géraud ${ }^{\text {a }}$, Marc Diraison ${ }^{\text {b }}$, PierreClément DAMY ${ }^{\mathrm{c}}$, Vivien Navelot ${ }^{\mathrm{a}}$, Sébastien Haffen ${ }^{\mathrm{a}}$.

a GeoRessources, UMR 7359 Université de Lorraine/ENSG, 2 rue du Doyen Marcel Roubault, Vandoeuvre-les-Nancy Cedex 54518, France.

b Institut de Physique du Globe (IPG), UMR 7516 CNRS-Université de Strasbourg/EOST, 5 rue René Descartes, Strasbourg Cedex 67084, France

${ }^{\mathrm{c}}$ Fonroche Géothermie, Technopôle Hélioparc, 2 av. Pierre Angot, 64053 Pau Cedex 9 France

Emails:

lionel.bertrand@univ-lorraine.fr +33 383596455 France

jessie.Jusseaume@gmail.com Present address

yves.geraud@univ-lorraine.fr

$\underline{\text { marc.diraison@unistra.fr }}$

pc.damy@fonroche.fr

vivien.navelot@univ-lorraine.fr

shaffen@teranov.fr Present address

Keywords: Fault hierarchization; fracture network; spatial arrangement; rifting context; basement rock 


\section{Abstract}

In fractured reservoirs in the basement of extensional basins, fault and fracture parameters like density, spacing and length distribution are key properties for modelling and prediction of reservoir properties and fluids flow. As only large faults are detectable using basin-scale geophysical investigations, these fine-scale parameters need to be inferred from faults and fractures in analogous rocks at the outcrop. In this study, we use the western shoulder of the Upper Rhine Graben as an outcropping analogue of several deep borehole projects in the basement of the graben. Geological regional data, DTM (Digital Terrain Model) mapping and outcrop studies with scanlines are used to determine the spatial arrangement of the faults from the regional to the reservoir scale. The data shows that: 1) The fault network can be hierarchized in three different orders of scale and structural blocks with a characteristic structuration. This is consistent with other basement rocks studies in other rifting system allowing the extrapolation of the important parameters for modelling. 2) In the structural blocks, the fracture network linked to the faults is linked to the interplay between rock facies variation linked to the rock emplacement and the rifting event.

\section{Introduction}

Currently there is renewed interest in magmatic and metamorphic rocks for the exploration of non-conventional reservoirs for geothermal projects, nuclear waste deposition, or petroleum prospects (Genter and Castaing, 1997; Luthi, 2005; Rempe, 2007; Cuong and Warren, 2009; Géraud et al., 2010; Marques et al., 2010). In these lithologies, the porosity and permeability are low in general, but several processes could increase porosity and lead to the development of a reservoir. Basement 
reservoirs are composed of two main parts: 1) a weathered layer located at the top of the basement, if the paleotopography and climatic conditions enable its development and if it is preserved when buried under the sedimentary infilling of the basins (Dewandel et al., 2006; Boiron et al., 2010; Aquilina and De Dreuzy, 2011; Cathelineau et al., 2012); 2) fault zones where a significant fault core and damage zone are developed, or a opening fracture network both of which can enhance a reservoir's properties if well connected (Caine et al., 1996; Forster et al., 1997; Nelson, 2001; Faulkner et al., 2010; Ameen et al., 2012; Hennings et al., 2012). Unfortunately, the detection of these structures is poor when using current geophysical investigation methods from the surface (Bertini et al., 2006; Luthi, 2005). Nonetheless, knowledge of their location and of reservoir properties are both critical for drilling projects and resource estimation.

To determine the fracture and fault network geometry and the inferred petrophysical properties (porosity and permeability), outcropping analogue rocks were analysed (McCaffrey et al., 2003) and the findings could help develop a reservoir model. Characteristics like the spacing of different fault sets, fault displacements and length distribution are key parameters for the comprehension and modelling of fractured reservoirs (Heffer and Bevan, 1990; Yielding et al., 1992; De Dreuzy et al., 2004; Berg and Øian, 2007). As most basement reservoirs are located in extensional contexts (Trice, 2014; Gutmanis et al., 2015), such parameters can be established by studying the basement at the shoulders of the rifts.

Most studies of fractured systems are concentrated on one lithology assumed to be the analogue of a basement reservoir. However, the basement's long geological history meant there were large variations in the petrology and a pre-existing fault 
network. According to the variability of these elements, the reactivation and extension processes could differ in the same basin depending on these heritages. Recent studies have particularly stressed the importance of the relation between structural heritage and extension-linked fault zones (Le Garzic et al., 2011; Murray and Montgomery, 2014; Slightam, 2014; Trice 2014; Bertrand et al., 2015). Parameters like damaged zone thickness, fracture density and orientation repartition and the hydraulic conductivity they may cause are directly linked to these heritage/reactivation processes (Laubach et al., 2014; Morley and Nixon, 2016).

The basement of the Upper Rhine Graben (URG) is the target for several future drilling projects, namely for geothermal prospection (Boissavy, 2016). Outcrops of the URG basement lie in the Black Forest and the Vosges Mountains (Edel and Schulmann, 2009; Lardeaux et al., 2014; Skrzypek et al., 2014). This study focuses on the Northern Vosges as the area has a high petrographic heterogeneity, with different metamorphic units and also several types of magmatic intrusions. The current state of the fault and fracture networks is the result of the structural inheritance affecting these lithologies dating from the Hercynian orogeny and their reactivations by later deformation events. We therefore performed a multiscale study based on geological data, DTM (Digital Terrain Model) photo-interpretation and fracture characterization in the field, with the aim of characterizing the fault and fractures pattern in light of the site's complex geological history. The findings were intended to allow us to discuss the fault structuration with the length, spacing and orientation parameters and the influence of the lithological variation of the fracture network parameters linked to the fault system. Finally, these elements will be compared to other rift shoulders. 


\section{Geological Context}

\subsection{The Hercynian orogeny}

The basement rock of the Mesozoic sedimentary basins in France is formed of litho-tectonic domains that are the result of subduction and collision events in Palaeozoic times during the Hercynian orogeny (Matte, 2001; Nance et al., 2010; Guy et al., 2011; Lardeaux et al., 2014) (Fig. 1). Initially, it consisted of the LaurentiaBaltica plate northward and the Gondwana plate southward, with several microcontinents like Armocia and Avalonia isolated from Gondwana and stuck to Laurentia-Baltica (Autran and Cogné, 1980; Bard et al., 1980, Paris and Robardet, 1990, Van der Voo, 1993; Cocks, 2000; Franke, 2000; Kemnitz et al., 2002; Robardet, 2003; Von Raumer et al., 2003).

In the Vosges Mountains, the Moldanubian domain, which is the metamorphic root of the orogeny, forms the Central and Southern Vosges Regions and the LAlayeLubine Fault Zone (LLFZ) separates them from the Northern Vosges (Schulmann et al., 2009). This study focuses on the Northern Vosges Region, which represents the juxtaposition of different rock types of the Teplà-Barrandian and Saxothuringian domains intruded upon by magmatic bodies (Fig. 1).

\section{'Insert Figure 1'}

Thus, the Northern Vosges are composed of a succession of rock units fixed together by ENE-WSW to E-W oriented thrusts (Fig. 2):

- The Southern Schists are the western termination of the Teplà-Barrandian Unit and date from the Cambro-Ordovician periods. They are pelitic sediments and tuff intercalations metamorphosed under greenschists-facies conditions (Doubinger and von Eller 1963; Tobschall, 1974; Reitz and Wickert, 1989; Skrzypek et al., 2014). 
- The Northern Bruche Unit dates from the Lower to late Upper Devonian periods and is composed of a succession of varied facies of detrital sediments and sparse carbonate lenses which testify to a coastal sedimentation with the erosion of Cambrian basement in a shallow-marine basin (Elsass et al., 2008, Skrzypek et al., 2014). The volcanic massif of Rabodeau-Schirmeck is mainly composed of spilite, keratophyre and volcanic breccias and intrudes upon this unit. Both units are metamorphosed under Barrovian conditions and represent the Saxothuringian domain in the area.

- The "Champ-du-Feu" magmatic massif intrudes upon the suture between the Saxothuringian and the Teplà-Barrandian domains. This massif is composed of a series of NE-SW to E-W trending plutons with a succession of granodiorites, diorites and granites dated from $334 \pm 5$ Ma to $319 \pm 3$ Ma (Deschamps, 1995; Altherr et al., 2000; Cocherie, 2007; Elsass et al., 2008; Tabaud et al., 2014). Later granites linked to this magmatic event crosscut the preceding units. The youngest is the Kagenfels granite which dates from $299 \pm 7$ Ma (Boutin et al., 1995) and marks the end of plutonism.

\section{- 'Insert Figure 2'}

\subsection{The post-hercynian tectonics}

From the Pennsylvanian onwards, the orogeny started to collapse and led to the formation of ENE-WSW elongated basins linked to high tectonic activity (Sittler, 1965; Roland, 1971, Illies, 1972; Schumacher, 2002). This activity is notably responsible for the formation of wide strike slips with NE-SW and NW-SE directions (Arthaud and Matte, 1975). The sedimentation progressively enlarged and expanded 
through the whole of Europe accompanied by a reduction in tectonic activity during the Permian and Triassic Periods (Durand, 1978; Guillocheau et al., 2000; Sissingh, 2001; Bourquin et al., 2006). The beginning of the Alpine cycle led to the formation of the Alps with a continental collision that started at the Eocene Epoch (Illies, 1972; Ziegler, 1992; Geyer and Gwinner, 1995; Walter, 1995; Schumacher, 2002). At this time, the rifting event leading to the URG formation began in response to the Alpine collision (Bourgeois et al., 2007; Edel et al., 1997; Roussé, 2006; Ford et al., 2007). In the URG, rifting began with N-S faults at the end of the Eocene Epoch with maximal activity during the Oligocene Epoch (Illies, 1972; Merle and Michon, 2001; Schumacher, 2002). Starting from the URG, the rifting extended progressively to the North and to the South, forming a succession of basins like the Limagne Graben, the Rhodanian Graben, etc. (Bourgeois et al., 2007). The rifting process, especially in the URG and helped by Alpine shortening, brought the Hercynian basement rock to the outcrop at the shoulders of the basin and formed the Vosges and Black Forest mountains as they are known today (Brun et al., 1992). During the Miocene Epoch, the Alpine collision persisted and there was a rotation of the extension direction which produced left-lateral movements on the N-S faults and reactivated the ENEWSW fault with right-lateral movements.

\section{Methodology}

\subsection{Fault analysis and DTM mapping}

Firstly, an analysis of the faults known from geological data in the area was carried out by the combination of geological maps at a 1/50 000 scale (Blanalt et al., 1972; Théobalt et al., 1975; von Eller et al., 1975; Ménillet et al., 1978) and recent structural studies (Elsass et al., 2008; Skrzypek et al., 2014). A general map with a 
classification of the faults in orientation was drawn. From this map, the trend of the regional faults of the area can be defined.

\section{'Insert Figure 3'}

Secondly, a structural study of the Northern Vosges Mountains based on manual extraction of lineaments from DTM photo-interpretation in GIS system was executed. This related to the $3 \mathrm{D}$ representation of the topographic surface obtained from elevation data. The DTMs come from the French National Geographic Institute's database (IGN, BD Alti®, RGF93 referential) with a resolution of 25 metres. Added to these processed topographic surfaces, the hydrological network's dataset $(I G N, B D$ Carthage $\left.{ }^{\circledR}\right)$ of the area was imported. Differential lighting angles (NE, SE, SW, NW) were used to illuminate the surface and to avoid overestimation of perpendicular lineaments compared with parallel lines, according to lighting (Fig. 3). This lighting was at an angle of $45^{\circ}$ to the horizontal plane. Thus, all structural lineaments on each shading angle are manually recorded. In this study, a lineament that had length and direction was considered to be a linear or slightly curvilinear structural unit (O'Leary et al., 1976; El Hadani, 1977). The plot covers all the area studied from the regional (1:500 $000-1: 250000)$ to the local scale (1:50 000) and was subsequently combined into a single plot to give a global multiscale overview.

\subsection{Outcrop analysis}

The aim of the outcrop study was to obtain statistical information concerning centimetric to metric length fractures, both close to and far from the main faults. On the outcrop, the fractures were measured in orientation and length along a scan line (SL) to avoid observation bias upon fracture counting. A statistical distribution of 
these parameters along a 1D direction was therefore obtained with the only bias being in the orientation linked to the outcrop geometry (Bonnet et al., 2001). The fractures which are sub-perpendicular to the outcrop were overestimated regarding the subparallel fractures (Pickering, 1995; Davy et al., 2006). Many studies address the question of the angular correction between the SL and the fracture sets used to avoid this sampling bias (Terzaghi, 1965; Pickering et al., 1995; Peacock et al., 2003; Wang, 2005; Davy et al., 2006; Bisdom et al., 2014). However, the SL we used were often multidirectional due to the outcrop conditions and involved mostly a combination of several outcrop planes rather than a strictly planar surface (Fig. 4). Thus, to be mathematically correct, Terzaghi's correction needed to be applied differently to each subsampling surface orientation rather than directly applied to the whole SL. We chose not to apply a systematic correction to our data for this reason and also because the SL we used are almost all in the direction of the studied area meaning we had no main sampling direction.

Taking account of this bias, the fracture orientation sets can be compared to the regional and DTM data. The orientations on each outcrop studied are plotted as a rose diagram taking into account the length of each fracture so as not to overestimate the short against the long fractures. The diagrams showing the number of fractures are not presented in this paper, as they are almost equivalent to those corrected for the length of all SL data.

'Insert Figure 4'

\section{Results}


The combination of structural data from the regional scale, DTMs and outcrop analysis, provides us a multiscale view of the brittle deformation in the Northern Vosges.

\subsection{First order faults organization}

\subsubsection{Bibliographic data}

The compilation of the bibliographic data from the known regional faults is presented in figure 5a. From the fault orientation and the geological background of the area, the faults have been reinterpreted and classified into four categories:

- $\quad$ The ENE-WSW to E-W trending faults (orange lines, Fig. 5a) mainly result from the Hercynian deformation, with a stack of units and the juxtaposition of the bands of different lithologies from the Southern Schists to the southern "Champ-duFeu" massif. They are later reactivated by the brittle deformation that has been demonstrated by associated catalases and fractures (Elsass et al., 2008) and represent $37.1 \%$ of the fault number and $36.1 \%$ of the length.

- The NE-SW trending faults (red lines, Fig. 5a), which were at least for the Kreuzweg fault zone are tardi-Hercynian strike-slips, with a posteriori reactivation (Arthaud and Matte, 1975; Elsass et al., 2008) during the Oligocene Epoch, with $10.3 \%$ in number and $10.3 \%$ in length.

- Other faults formed during the end of the Hercynian orogeny, with $37.1 \%$ of fault number and $36.1 \%$ of length and a NW-SE trend, (blue lines, Fig. 5a) that especially make right-lateral shifts in the "Champ-du-Feu" massif (Arthaud and Matte, 1975; Elsass et al., 2008). The NW-SE and NE-SW faults probably acted as a conjugate system before the later reactivation events.

- Finally, the N-S faults (black lines, Fig. 5a) were present also during the Hercynian orogeny, but were mainly reactivated during the Oligocene extension at the 
beginning of the West European Rifting event (Roland, 1971; Illies, 1972; Elsass et al., 2008). They represent $20 \%$ of the fault number and $29.3 \%$ of the fault length.

\section{'Insert Figure 5'}

The compilation of these data and the classification of the faults in four families enabled us to divide the area into three parts with a characteristic spatial arrangement of the faults in each structural block (Fig. 5a):

- The western area is separated from the other parts by the Saales fault, with a low fault density $\left(0.29 \mathrm{f} . \mathrm{km}^{-2}\right)$ and no relevant spatial structuration of the different fault families.

- At the eastern side of the Saales fault, i.e. the central area in the "Champ-duFeu" massif, the N-S and ENE-WSW trends are clearly dominant, respectively representing $26.5 \%$ and $45.2 \%$ of the fault number and $47.5 \%$ and $31.5 \%$ of the fault length. This structural block has a medium fault density with $0.53 \mathrm{f} . \mathrm{km}^{-2}$.

- In the northern part, i.e. the Bruche-Schirmeck and the Permo-Triassic units, the main fault orientations are NE-SW (23.0\% in number and $25.7 \%$ in length) and ENE-WSW (22.9\% in number and $26.7 \%$ in length), with the highest fault density $\left(0.74\right.$ f. $\left.\mathrm{km}^{-2}\right)$

\subsubsection{DTM data}

The structural map obtained after manual picking from the DTM data contains 1426 lineaments (Fig. 5b). Despite a shift of the ENE-WSW in two subsets of ENEWSW and E-W orientations, the main directions highlighted by the map correspond well to the geological features. Thus, an N-S trend is dominant in the diagram in lineament number at $25.6 \%$ and the secondary sets are NW-SE and E-W with $15.5 \%$ 
and $16.7 \%$ respectively and finally to a lesser extent NE-SW with $10.7 \%$. With weighting by length, the N-S was found to scatter slightly (19.8\%) in favour of NWSE (19.4\%) and ENE-WSW (9.2\%).

The DTM data also correspond to the separation in three distinct areas observable in the regional faults (Fig. 5c):

- In the western area, the lineaments' orientations are scattered. The dominant directions N-W and E-W could be distinguished in the number diagram but this was found to be no longer the case when length weighting was applied.

- In the central area, N-S and E-W directions are the dominant orientation, with respectively $25.4 \%$ in number and $24.2 \%$ in length, and $23.0 \%$ in number and $22.2 \%$ in length. There are also lineaments in the NW-SE direction with $12.7 \%$ in number and $13.1 \%$ in length.

- The northern area is dominated in the frequency number diagram and also in the length frequency by the N-S (20.0-15.4\%) and NW-SE (27.6-25.8\%) directions. Two peaks at $10 \%$ appear on the diagram in length. These are the reflection of the Raon l'Etape - Donon and the Champenay - Schirmeck Valleys.

Thus, both the geological and DTM data correspond to a separation of the studied area into three sub-areas with their own fault densities and orientations. In the western area, the faults are sparse, while there is a high density of NE-SW and NE-SW faults in the northern area. In the central area, the fault density is medium with NW-SE, N-S and also ENE-WNW faults. In the newt section, we will focus on the spatial arrangement of the faults in the central and northern blocks.

\subsection{Faults by areas}




\subsubsection{Length distribution}

The length distribution for the DTM data (Fig. 6a) and the geological map (Fig. $6 b)$ are presented in a cumulative number diagram. Both sets of data show a length distribution in power-law with an exponent of -2.0 outside the range of biased data by truncature and censoring (Bonnet et al., 2001). However, in the geological data, a second power-law distribution was identified in the faults $<3 \mathrm{~km}$, with an exponent of -1.0 (Fig. $6 b$ ). The faults of length $<3 \mathrm{~km}$ are shown in bold in figure $6 c$. This demonstrates that these faults are mainly: 1) the ENE-WSW to E-W faults in the "Champ-du-Feu" magmatic massif, highly segmented by the reactivated fault sets N$\mathrm{S}$ and NW-SE and, 2) a large part of the faults in the northern area.

\section{'Insert Figure 6'}

\subsubsection{Fault spacing}

The spacing of the main fault sets, i.e. N-S and E-W in the central area and NESW and NW-SE in the northern area, was calculated along four SLs (Fig. 6d). Each SL is perpendicular to the studied set to avoid sampling bias due to the orientation of the faults with respect to the SL. For the four sets of faults analysed, the mean spacing was found to range from 9.8 to $1.4 \mathrm{~km}$, with correlation coefficient $\mathrm{Cv}<1$ indicating a regular spacing (Fig. 6e).

To summarize, the fault structure in the central and northern block is different in orientation, density and length distribution as highlighted by the geological and DTM data. However, the spacing of the internal block faults is almost the same, with the creation of structural blocks of $1 \mathrm{~km}$ in width between the two dominant sets of fault 
in each area. With the outcrop scale in the next section, we will describe the fracture system associated to these faults, in light of this three blocks and the variation of rock lithologies.

\title{
4.3. Outcrop scale
}

The fractures were studied on 35 outcrops distributed in the basement formation and the immediate Triassic or Permian coverage (Fig. 7). For the Moyenmoutier fault zone, the fracture orientations were extracted from the fracture map derived from photographs (outcrop 21, Tab. 4). For outcrops 22 to 25, $29 \& 33$, the main fractures were measured without precise statistics on the outcrop. For all other outcrops, the fractures were statistically measured along a scan line and the characteristics are summarized in table 1. As the exposure of the outcrops was always limited to few meters and the main faults mostly located in the eroded valleys, it was not possible to determine the precise distance from the regional faults. Thus, only the neighbouring fault orientation is discussed with the exception of 4 outcrops where minor fault cores with hydrothermal alteration and highly fractured clusters were recognized (outcrop $4,8,12,21$, bolded in tab. 1), These were near to the main fault slip surface unlike the others which are in the damaged zone a long way from the main fault core. For most of the outcrops, all the fractures are closed with very poor kinematics criteria and/or secondary minerals on the slip surface which means the relative timing of the fractures' formation cannot be discussed.

\author{
'Insert Figure 7' \\ 'Insert Table 1'
}


In the central area, in the northern and tardi-Hercynian granites, the dominant fracture set for all outcrops is N-S and is linked to the proximity of the N-S faults (outcrops 1 to 5, Fig. 7). The other sets of faults are only represented on secondary fractures' orientation, if there is a regional fault in the vicinity like the NW-SE on outcrop 5 or not like the E-W on outcrop 1.

In the magmatic bodies of the southern part, the fracture network is mostly controlled by the ENE-WSW to E-W Hercynian thrust, even if N-S or NW-SE faults are close to the outcrops (outcrops 6 to 9, Fig. 7). Other fracture directions are only observable near to the Kreuzweg NE-SW fault zone (outcrop 12-13, Fig. 7) and in the Southern Schists where the dominant fracture set is NW-SE despite the proximity of faults with various orientations (outcrops 10, $14 \&$ 15, Fig. 7). Finally, outcrop 11 in the Andlau granite shows a sparse fracture network mainly in NE-SW and ENE-WSW to E-W direction, despite the vicinity of N-S and NW-SE faults.

In the metamorphic units of the western and the northern area, there is no apparent link between the fracture network and the regional faults. For outcrops 17, 19, 21 to 26 , the fracture sets are sparse in general with poor links to the fault direction in the vicinity of the outcrop (Fig.7 \& tab. 1). For outcrops 16, 18 and 20, one fracture set dominates the fracture network but it is only linked to the regional fault on outcrop 20 with the $\approx \mathrm{E}-\mathrm{W}$ set. Conversely, in the Donon and Nideck valleys where the outcrops are mostly in the Triassic and Permian coverage, the dominant fracture sets are mostly NE-SW and NW-SE, even if the fault in the vicinity is N-S on outcrops 29, 30, 33, 34 and 35 (outcrop 27 to 35, Fig. 7 and tab. 1).

To summarize, the study of the fracture network shows that in the different areas, there are different fracture patterns depending on petrographic variations and 
the structural inheritance involved. Thus, in the central area, the granitic part displays mostly N-S faults related fractures while the fracture network is controlled by the Herycnian ENE-WSW direction. In the metamorphic units of the western and central part, the fractures are almost sparse while in the Triassic and Permian units of the northern part, the dominant fracture sets are linked to the NW-SE and NE-SW faults.

The differentiation by rock type is also observable in the fracture densities: the granite outcrops have $\approx 7-11 \mathrm{~m}^{-1}$ in the most outcrops to $\approx 30 \mathrm{~m}^{-1}$ in the highly fractured damaged zones (outcrop 4 and 12, tab. 1). The other magmatic units and the metamorphic units in the southern and northern parts have slightly higher densities, between $\approx 10-17 \mathrm{~m}^{-1}$ to $\approx 38 \mathrm{~m}^{-1}$, while the Triassic and Permian sediments or volcanics have almost the same fracture density range as granite (Tab. 1).

\section{Discussion}

The compilation of the recent and older geological data of the fault network, combined to our analysis of DTM data and the fracture network at the outcrop enabled us to make new interpretation of the fault network in the northern Vosges. Thus, a new structural model can be created and compared to other rift shoulders where the basement of the rift outcrops. This model would therefore be helpful for prospecting and more specifically for the prediction of fault structuration in the basement of basins linked to rifting systems.

\subsection{Structural model of the Northern Vosges}

The fault density and the main orientation on the DTM and geological data show a separation of the studied area in three first-order structural blocks. These structural 
blocks are limited by first-order faults and are $\approx 20 \mathrm{~km}$ wide (Fig. 8). Thus, the central block is limited at the East by the bordering fault of the rift basin and at the West by the first-order Saales fault. At the west side of the latter, in the western block, the structuration in "bands" of the lithologies and the N-S faults reactivated during the rifting event are no longer present as the orientation diagrams and the low fault density both show. The same data highlights a differentiation in the fault structuration between the central and the northern block although there is no apparent first-order fault which disconnects the brittle deformation (dashed line, fig. 8).

The internal structure of the first-order blocks, in particular the central and the northern blocks, show a specific spatial arrangement of the faults. In the central block, the main faults are N-S and NW-SE, with also the presence of the ENE-WSW to E-W direction linked to the bands of lithologies. Two faults of the N-S (Brimbeliere and Magel faults, fig. 8) and the NW-SE sets (Waldersbach and Natzwiller faults, fig. 8) are the longest faults in the block and also control the main topographic changes in the massif (Elsass et al., 2008). Thus, these faults can be considered as second-order faults, organizing the basement rock into second-order blocks with a regular width of 4-5 km. Within the second-order blocks, the spacing data of the N-S and NW-SE fault sets show regular spacing $(\mathrm{Cv}<1)$ and in consequence an individualization in thirdorder blocks of $1-2 \mathrm{~km}$ in width.

In the northern block, the data show a high density of short faults, leading to a change in the power-law distribution (Fig. 6b), with the main faults' direction being NW-SE and NE-SW. Thus, while second-order structuration is not observable because the most part of the faults are short, the SLs show regular spacing with a $\mathrm{Cv}$ 
$<1$ for the NW-SE and NE-SW sets. In this first-order block, the fault structuration is therefore controlled by third-order faults that individualize blocks of 1-2 km in width.

To summarize, our new structural model proposes a structuration in first-, secondand third-order faults and structural blocks with characteristic length, density and spacing distribution with each first-order block having their own internal fault structuration. In the next section this model will being compared with other rift shoulders.

\subsection{Comparison with other rift shoulders}

Recent studies have shown that in rifting contexts, the brittle structure of the basement rock can be hierarchized according to fault parameters like length, spacing, displacement and thickness. Indeed, structural studies of the Al-Mukalla basement (Northern Aden gulf) and the Catalonian margin (NE Spain) (Le Garzic, 2010; Place, 2010; Bertrand et al., 2015), the compilation of Morellato et al. (2003) in different extensional systems and also studies of the relation between the different fault parameters (Gillespie et al., 1993; Pickering et al., 1995; Clark and Cox, 1996; Peacock et al., 2003; Childs et al., 2009) all emphasize a characteristic arrangement of faults.

Thus, through analysis of the 2D distribution (Le Garzic et al., 2011), three orders of faults were defined. This structuration has been identified in the URG with the seismic prospection in the sedimentary units (Fig. 9a), with:

1) The first-order faults accommodate the crustal scale deformation, like the Vosgian fault in the area studied, and brought the basement rock to the surface (red, fig. 9a). 
2) The second-order faults form the horst and graben structures in the extensional system. In these second-order blocks, faults of approximately $10 \mathrm{~km}$ in length decompose the basement rocks in horsts or grabens (blue, fig. 9a).

3) The third-order faults are formed in second-order blocks and are typically visible on DTM data by the associated eroded valleys (green, fig. $9 a$ ).

As the basement faults are poorly constrained by seismic prospection because of the investigation depth and the absence of layering in the plutonic rocks, our structural analysis of the rift shoulders gives an example of prolongation of the fault network in the basement. As this structuration is also recognizable in other rift systems, it gives key parameters for reservoir modelling in fault zones. Thus, the length distribution and the classification in three orders could be directly used to predict fault key parameters for modelling like the displacement and the width (damaged zone width) of the fault zone (Fig. 9b).

\subsection{Structural heritage and fracture network}

As the faults parameters in the basin are predictable with the three orders of fault arrangement, our fracture network characterization on the outcrop enables modelling of the fracture network in the damaged zone in light of the petrographic variability of the basin basement.

As shown in our outcrop data, the interplay between the Oligocene extension and the inherited structures seems to have played a key role in the development of the fault and fracture system. Thus, each first-order block has their own second- and third-order fault network, with characteristic densities and orientation, although the general classification in three orders is valid at the regional scale. 
In the northern block and also in the granitic bodies of the central block, the fracture network's main orientation is controlled by the orientation of the main fault sets. These faults are NW-SE and NE-SW in the northern block and N-S and NW-SE in the central block. In the southern units of the central block, these faults have no influence on the fracture network which is dominated by ENE-WSW to E-W direction, linked to the Hercynian faults. Also, the magmatic fabric studied by Skrzypek (2011) shows a dominant N-S trend in the North and ENE-WSW in the South. Thus, the final state of the fracture network reflects the difference in the structural inheritance between the North and the South of the block. While the intrablock fracturing is controlled by the N-S and NW-SE structures in the northern part, their influence in the southern part is only minor.

As matrix porosity and permeability is generally low in these kinds of rocks, modelling the fracture network is a key aspect for the flow prediction in the basement of the basins (Nelson, 2001). These fractures are not observable in the pre-drilling data and the study of the Northern Vosges is a good example of analogous rocks with a high petrographic heterogeneity. Our comparison of the granitic and non-granitic parts of the structural blocks shows that the fracture network can be specific to each rock facies, linked to the different structural inheritance, even if the fault network is homogeneous.

\section{Conclusion}

The fault and fracture network of basement rocks is the subject of many studies because these structures are the main fluid flow conduits at depth in basins. With the high investigation depth and the absence of seismic markers in this type of geological context, the characterization of the fault and fracture network in outcrop can be helpful for fluid flow prediction. Our case study in the Northern Vosges on the 
shoulders of the URG highlights important structural features that can be helpful for prospecting in the basin and also can be generalized to other rift systems.

As described by previous authors, the fault network at the outcrop and in the URG is the result of the Hercynian pre-structuration and the reactivation processes during the latter deformation events, in particular the URG formation (Illies, 1972; Schumacher, 2002). This interplay between structural inheritance and latter deformation creates a fault spatial arrangement in three orders of scale, which have been identified in the basin sediments and also in other rift systems (Morellato et al., 2003; Le Garzic, 2010; Place, 2010; Bertrand et al., 2015). These three orders of faults have characteristic spacing and length. The largest, first-order blocks individualize large areas with differing sets and orientation and density patterns. With this broad differentiation of the basement patterns, other fine-scale parameters like fault damage zone thickness can be extrapolated from existing laws. This procedure allows fault networks at the base of basins to be modelled.

For modelling the fracture network associated with the faults, our structural analysis shows the importance of petrographic variation in the basement. Thus, in the rock facies where there is a structural inheritance of fabrics and lithologies related to igneous and metamorphic processes (magmatic fabric, early thrusts or strike-slip, ...), the fracture network will have different expression, even if the fault network is homogenous throughout the whole first-order block. This observation has a significant impact of flow modelling in the damage zone of the prospected faults, as the fractures could have completely different parameters from one rock facies of the basement to another. 


\section{Acknowledgments}

This paper is the first published work of the PhD thesis of Lionel Bertrand, in collaboration with Fonroche Geothermie and GeoRessources. The authors would like to thank the National Geographic Institute of France for providing the elevation data used in this study.

\section{References}

Altherr, R., Holl, A., Hegner, E., Langer, A., Kreuzer, H., 2000. High-potassium, calcalkaline I-type plutonism in the European Variscides: northern Vosges (France) and northern Schwarzwald (Germany). Lithos 50, 51-73.

Ameen, M. S., MacPherson, K., Al-Marhoon, M. I., Rahim, Z., 2012. Diverse fracture properties and their impact on performance in conventional and tight-gas reservoirs, Saudi Arabia: The Unayzah, South Haradh case study. AAPG Bulletin 96, n³, 459-492.

Aquilina, L., De Dreuzy, J-R., 2011. Relationship of present saline fluid with paleomigration of basinal brines at the basement/sediment interface (Southeast basin - France). Applied Geochemistry 26, 1933-1945.

Arthaud, F., Matte, Ph, 1975. Les decrochements tardi-hercyniens du Sud-Ouest de l'Europe, geometrie et essai de reconstitution des conditions de la déformation. Tectonophysics 25, 139-171.

Autran, A., Cogné, J., 1980. La zone interne de l'orogenèse varisque dans l'Ouest de la France et sa place dans le développement de la chaîne hercynienne. In: Géologie de l'Europe. $26^{\circ}$ C.G.I. Paris. Mémoire BRGM, Orléans, 108, 90 -111.

Bard J.P., Burg J.P., Matte P., Ribeiro A., 1980. La chaîne hercynienne d'Europe occidentale en termes de tectonique des plaques. In: Géologie de l'Europe. 26e C.G.I. Paris. Mémoire BRGM, Orléans, 108, 233 - 246.

Blanalt J.G., von Eller J.P., Fluck P., Geffroy J., Jeannette D., Ruhland M., Schwoerer P., Thévenin A., Stieber A., Vogt H, 1972. Carte géologique de Sélestat. BRGM geological map $\mathrm{n}^{\circ} 307$, scale 1:50,000.

Berg, S.S., Øian, E., 2007. Hierarchical approach for simulating fluid flow in normal fault zones. Petroleum Geoscience 13, 25-35.

Bertini ,G., Casini, M., Gianelli, G., Pandeli, E., 2006. Geological structure of a long-living geothermal system, Larderello, Italy. Terra Nova 18, 163-169. doi:10.1111/j.13653121.2006.00676.x.

Bertrand, L., Géraud, Y., Le Garzic, E., Place, J., Diraison, M., Walter, B., Haffen, S., 2015. A multiscale analysis of a fracture pattern in granite: A case study of the Tamariu granite, Catalunya, Spain. Journal of Structural Geology 78, 52-66.

Bisdom, K., Gauthier, B.D.M., Bertotti, G., Hardebol, N.J., 2014. Calibrating discrete fracture-network models with a carbonate three-dimensional outcrop fracture network: Implications for naturally fractured reservoir modelling. AAPG Bulletin 98, n7, 1351-1376. 
Boiron, M-C., Cathelineau, M., Richard, A., 2010. Fluid flows and metal deposition near basement /cover unconformity: lessons and analogies from $\mathrm{Pb}-\mathrm{Zn}-\mathrm{F}-\mathrm{Ba}$ systems for the understanding of Proterozoic U deposits. Geofluids 10, 270-292.

Boissavy, C., Rocher, P., Laplaige, P., Brange, C., 2016. Geothermal Energy Use, Country Update for France. European Geothermal Congress 2016 Proceedings, Strasbourg, 19-24 Sept 2016.

Bonnet, E., Bour, O., Odling, N.E., Davy, P., Main, I., Cowie, P., Berkowitz, B., 2001. Scaling of fracture systems in geological media. Reviews of Geophysics, 39, $\mathrm{n}^{\circ}$ 3, 347-383.

Bourgeois, O., Ford, M., Diraison, M., Le Carlier de Veslud, C., Gerbault., M., Pik, Ruby, N., Bonnet, S., 2007. Separation of tifting and lithospheric folding signatures in the NW-Alpine foreland. International Journal of Earth Sciences 96, 1003-1031.

Bourquin, C., Peron, S., Durand, M., 2006. Lower Triassic sequence stratigraphy of the western part of the Germanic Basin (west of Black Forest): Fluvial system evolution through time and space. Sedimentary Geology, 186, 187-211

Boutin, R., Montigny, R., Thuizat, R., 1995. Chronologie K-Ar et ${ }^{39} \mathrm{Ar}-{ }^{40} \mathrm{Ar}$ du métamorphisme et du magmatisme des Vosges. Comparaison avec les massifs varisques voisins. Géologie de la France 1, 3-25.

Brun, J.P., Gutscher, M.A., DEKORP-ECORS teams, 1992. Deep crustal structure of the Rhine Graben from DEKORP-ECORS seismic reflection data: a summary. Tectonophysics 208, 139-147.

Caine, J.S., Evans, J.P., Forster, C.B., 1996. Fault zone architecture and permeability structure. Geology 24, 1025-1028.

Cathelineau, M., Boiron, M.C., Fourcade, S., Ruffet, G., Clauer, N., Belcourt, O., Coulibaly, Y., Banks, D.A., Guillocheau, F., 2012. A major Late Jurassic fluid event at the basin/basement unconformity in western France: ${ }^{40} \mathrm{Ar} /{ }^{39} \mathrm{Ar}$ and $\mathrm{K}-\mathrm{Ar}$ dating, fluid chemistry, and related geodynamic context. Chemical Geology 322-323, 99-120.

Childs, C., Manzocchi, T., Walsh ,J.J., Bonson, C.G., Nicol, A., Schöpfer ,M. P.J., 2009. A geometric model of fault zone and fault rock thickness variations. Journal of Structural Geology 31, 117-127.

Clark, R.M., Cox, S.J.D., 1996. A modern regression approach to determining fault displacement-length scaling relationships. Journal of Structural Geology 18, 147-152. doi:10.1016/S0191-8141(96)80040-X

Cocherie A., 2007. Datations U-Pb (laser-ICPMS-MC) sur zircons des Vosges (projet carte 50 000). Note $N^{\circ} M M A / I S O-2007 / 262,15 \mathrm{p}$.

Cocks, L. R. M., 2000. The Early Palaeozoic geography of Europe. Journal of the Geological Society of London, vol. 157, 1-10.

Cuong, T.X., Warren, J.K., 2009. Back Ho Filed, a fractured granitic basement reservoir, Cuu Long basin, offshore se Vietnam: a "buried-hill" play. Journal of Petroleum Geology 32, 129156. 
Davy, P., Darcel, C., Bour, O., Munier, R., De Dreuzy, J.R., 2006. A note on the angular correction applied to fracture intensity profiles along drill core. Journal of Geophysical Research 111, B11408. http://dx.doi.org/10.1029/2005JB004121.

Deschamps, M., 1995. Le magmatisme du Champ du Feu (Vosges septentrionales): caractérisation et signification géodynamique. Bulletin des Académie et Société Lorraines des Sciences 34, 131-149.

De Dreuzy, J.R., Darcel, C., Davy, P., Bour, O., 2004. Influence of spatial correlation of fracture centers on the permeability of two-dimensional fracture networks following a power law length distribution. Water Resources Research 40, W01502. Doi:10.1029/2003WR002260.

Dewandel, B., Lachassagne, P., Wyns, R., Maréchal, J.C., Krishnamurthy, N.S., 2006. A generalized 3-D geological and hydrogeological conceptual model of granite aquifers controlled by single or multiphase weathering. Journal of Hydrology 330, 260- 284.

Doubinger, J., von Eller, J.P., 1963. Présence de Spongiaires dans les schistes précambriens métamorphiques des Vosges. Bulletin du Service de la Carte Géologique d'Alsace-Lorraine $16,111-123$.

Doubinger, J., 1965. Sur l'âge des gisements houillers des Vosges. Bulletin du Service de la Carte Géologique d'Alsace-Lorraine 18, 49-64.

Durand, M., 1978. Paléocourants et reconstitution paléogéographique - L'exemple du Buntsandstein des Vosges Méridionales (Trias inférieur et moyen continental). Sciences de la Terre, Tome WWII, n² 3 301-390.

Edel, J.B., 1997. Les réaimantations post-permiennes dans le bassin dévono-dinantien des Vosges méridionales: existence d'une phase de réaimantation au Lias, contemporaine d'une phase de minéralisation d'ampleur régionale. Compte Rendu de l'académie des Sciences de Paris 324, 617-624.

Edel, J.M., Schulmann, K., 2009. Geophysical constraints and model of the "Saxothuringian and Rhenohercynian subductions - magmatic arc system" in NE France and SW Germany. Bulletin de la Société géologique de France 180, nº 6, 545-558.

El Hadani, D. 1997. Télédétection et Systèmes d'Information Géographique pour la gestion et la recherche de l'eau. Géo-Observateur. Les Rapports Thématiques $1: 28$.

Elsass P., von Eller J.P., Stussi J.M., 2008. Géologie du massif du Champ du Feu et de ses abords. Eléments de notice pour la feuille géologique 307 Sélestat. Rapport BRGN RP56088-FR.

Faulkner, D.R., Jackson, C.A.L., Lunn, R.J., Schlische, R.W., Shipton, Z.K., Wibberley, C.A.J., Withjack, M.O., 2010. A review of recent developments con- cerning the structure, mechanics and fluid flow properties of fault zones. Journal of Structural Geology 32, 15571575 .

Ford, M., Le Carlier de Veslud, C., Bourgeois, O., 2007. Kinematic and geometric analysis of fault-related folds in a rift setting: The Dannemarie basin, Upper Rhine Graben. Journal of Structural Geology 29, 1811-1830. 
Forster, C.B., Caine, J.S., Schultz, S., Nielson, D.L., 1997. Fault zone architecture and fluid flow an example from Dixie Valley, Nevada. In: Proceedings, Twenty- second Workshop on Geothermal Reservoir Engineering. Stanford University, Stanford, California, 27-29.

Franke, W., 2000. The mid-European segment of the Variscides: tectonostratigraphic units, terrane boundaries and kinematic evolution. In: Franke, W., Haak, V., Oncken, O. \& Tanner, D. (eds.) Orogenic Processes: Quantification and Modelling in the Variscan Belt, Geological Society Special Publication, London 179, 35-63.

Genter, A., Castaing, C., 1997. Effets d'echelle dans la fracturation des granites. Tectonics $325,439-445$.

Géraud, Y., Rosener, M., Surma, F., Place, J., Le Garzic, E., Diraison, M., 2010. Physical properties of fault zones within a granite body: example of the Soultz-sous- Forêts geothermal site. Comptes Rendus Geosciences 242, 566-574.

Geyer, O. F., Gwinner M. P., 1995. Geologie von Baden-Württemberg, 472 p., Schweizerbart, Stuttgart, Germany.

Gillespie, P.A., Howard, C.B., Walsh, J.J., Watterson, J., 1993. Measurement and characterisation of spatial distributions of fractures. Tectonophysics 226, 113-141.

Guillocheau, F., Robin, C., Allemand, P., Bourquin, S., Brault, N., Dromart, G., Friedenberg, R., Garcia, J.-P., Gaulier, J.-M., Gaumet, F., Grosdoy, B., Hanot, F., Le Strat, P., Mettraux, M., Nalpas, T., Prijac, C., Rigollet, C., Serrano, O., Grandjean, G., 2000. Meso-Cenozoic geodynamic evolution of the Paris basin: 3D stratigraphic constraints. Geodynamica Acta 13, 189-245.

Gutmanis, J.C., Bachelor, T., Doe, S., Pascual-Cebrian, E., 2015. Hydrocarbon production from fractured basement formations. Public report, version 11, p.45.

Heffer, K.J., Bevan, T.G., 1990. Scaling relationships in natural fractures: data, theory, and application. In: European Petroleum Conference, 21-24 October 1990, the Hague, Netherlands.

Hennings, P., Allwardt, P., Paul, P., Zahm, C., Reid Jr, R., Alley, H., Kirschner, R., Lee, B., Hough, E., 2012. Relationship between fractures, fault zones, stress, and reservoir productivity in the Suban gas field, Sumatra, Indonesia. AAPG Bulletin 96, n4, 753-772.

Illies, J.H., 1972. The Rhine graben rift system - plate tectonics and transform faulting. Geophysical Surveys 1, 27-60.

Kemnitz, H., Romer, R. L., Oncken, O., 2002. Gondwana breakup and the northern margin of the Saxothuringian belt (Variscides of Central Europe). Geologische Rundschau 91, 246-259.

Lardeaux, J.M., Schulmann, K., Faure, M., Janousěk, V., Lexa, O., Skrzypek, E., Edel, J.B., Štípská P., 2014. The Moldanubian Zone in the French Massif Central, Vosges/Schwarzwald and Bohemian Massif revisited: differences and similarities. In: Schulmann, K., Martinez, Catalan, J.R., Lardeaux, J.M., Janousěk, V., Oggiano, G. (eds) 2014. The Variscan Orogeny: Extent, Timescale and the Formation of the European Crust. Geological Society, London, Special Publications, 405, 7-44.

Laubach, S.E., Eichhubl, P., Hargrove, P., Ellis, M.A., Hooker, J.N., 2014. Fault core and damage zone fracture attributes vary along strike owing to interaction of fracture growth, 
quartz accumulation, and differing sandstone composition. Journal of Structural Geology 68, 207-226. doi: 10.1016/j.jsg.2014.08.007

Le Garzic, E., 2010. Distribution multi-echelle de la fracturation dans les réservoirs cristallins, influence de l'héritage structural. University of Strasbourg, France, p. 268. PhD thesis.

Le Garzic, E., de L'Hamaide, T., Diraison, M., Géraud, Y., Sausse J., de Urreiztieta, M., Hauville, B., Champanhet, J.M., 2011. Scaling and geometric properties of extensional fracture systems in the proterozoic basement of Yemen. Tectonic interpretation and fluid flow implications. Journal of Structural Geology 33, 519-536.

Luthi, S.M., 2005. Fractured reservoir analysis using modern geophysical well techniques: application to basement reservoirs in Vietnam. Special Publications 240. In: Harvey, P.K., Brewer, T.S., Pezard, P.A., Petrov, V.A. (Eds.), Petrophysical Properties of Crystalline Rocks. Geological Society, London, pp. 95-106.

Marques, J.M., Matias, M.J., Basto, M.J., Carreira, P.M., Aires-Barros, L.A., Goff, F.E., 2010. Hydrothermal alteration of Hercynian granites, its significance to the evolution of geothermal systems in granitic rocks. Geothermics 39, 152-160.

Matte P., 2001. The Variscan collage and orogeny (480 $\pm 290 \mathrm{Ma})$ and the tectonic definition of the Armorica microplate: a review. Terra Nova 13, 122-128.

McCaffrey, K.J.W., Sleight, J.M., Pugliese, S., Holdsworth, R.E., 2003. Fracture formation and evolution in crystalline rocks: Insights from attribute analysis. In: Petford, N., McCaffrey, K.J.W. (Eds.), Hydrocarbons in Crystalline Rocks. Geological Society, London, pp. 109-124. Special Publications 214.

Merle, O., Michon L., 2001. The formation of the West European rift: A new model as exemplified by the Massif Central area. Bulletin de la Société Geoléologique de France 172, $\mathrm{n}^{\circ} 2,213-221$.

Ménillet, F., Durand, M., Maïaux, C., Lougnon, J., 1978. Carte géologique de Cirey-surVezouze. BRGM geological map n²70, scale 1:50,000.

Mihara, S., 1935. Etude géologique et pétrographique de la région du Nideck. Mémoire des Services de la Carte géologique d'Alsace Lorraine 4, 134 p.

Morellato, C., Redini, F., Doglioni, C., 2003. On the number and spacing of faults. Terra Nova 15, 315-321. doi: 10.1046/j.1365-3121.2003.00501.x

Morley, C.K., Nixon, C.W., 2016. Topological characteristics of simple and complex normal fault networks. Journal of Structural Geology 84, 68-84.

Murray, A., Montgomery, D.W., 2014. Characterization of highly fractured basement, Say'un Masila Basin, Yemen, in Advances in the Study of Fractured Reservoirs, edited by G. H. Spence, J., Redfern, R., Aguilera, T.G., Bevan, J.W., Cosgrove, G.D., Couples, J.-M., Daniel, pp. 289-310, Geological Society.

Nance, R.D., Gutiérrez-Alonso, G., Keppie, J.D., Linnemann, U., Murphy, J.B., Quesada, C., Strachan, R.A., Woodcock, N.H., 2010. Evolution of the Rheic Ocean. Gondwana Research 17, 194-222. 
Nelson, R.A., 2001. Geological Analysis of Naturally Fractured Reservoirs, Second ed. Gulf Professional Publishing, p. 332.

O’Leary, D.W., Friedmann, J.D., Pohn, H.A., 1976. Lineament, linear, lineation: Some proposed new standards for old terms. Geological Society of America Bulletin 87, n¹0, 1463-1469.

Paris, F., Robardet, M., 1990. Early Paleozoic paleogeography of the Variscan regions. Tectonophysics 177, 193-213.

Peacock, D.C.P., Harris, S.D., Mauldon, M., 2003. Use of curved scanlines and boreholes to predict fracture frequencies. Journal of Structural Geology 25, 109-119.

Pickering, G., Bull, J.M., Sanderson, D.J., 1995. Sampling power-law distributions. Tectonophysics 248, 1-20.

Place, J., 2010. Caractérisation des chemins de circulations de fluides dans le réseau poreux d'un batholite granitique. University of Strasbourg, France, p. 360, PhD Thesis.

Reitz, E., Wickert, F., 1989. Late Cambrian to early Ordovician acritarchs from the Ville' Unit, northern Vosges Mountains (France). Neues Jahrbuch für Geologie und Paläontologie, Monatshefte 6, 375-384.

Rempe, N.T., 2007. Permanent underground repositories for radioactive waste. Progress in Nuclear Energy 49, 365-374. http://dx.doi.org/10.1016/j.pnucene.2007.04.002.

Robardet, M., Blaise, J., Bouyx, E., Gouvernnec, R., Lardeux, H., Le Hérissé, A., Le Menn, J., Melou, M., Paris, F., Plusquellec, Y., Poncet, J., Régnault ,S., Rioult ,M., Weyant, M., 2003. Paléogéographie de l'Europe occidentale de l'Ordovicien au Dévonien. Bulletin de la Société Géologique de France 164, n5, 683-695.

Rolland, A., 1975. Fracturation et géomorphologie dans le socle vosgien, essai de comparaison avec la Forêt Noire. Metz university, Phd thesis, 256 p.

Rousse, S., 2006. Architecture et dynamique des series marines et continentals de l'Oligocène Moyen et Supérieur du Sud du Fossé Rhénan: Evolution des milieux de depot en context de rift en marge de l'avant-pays alpin. Strasbourg University, Phd Thesis, 483p.

Saucier, H., Millot, G., Jost, R., 1959. Les ignimbrites permiennes de la région du Nideck (Vosges-Alsace). Bulletin du Service de la Carte Géologique d'Alsace Lorraine 12, n², 33.

Schulmann, K., Konopásek, J., Janoušek, V., Lexa, O., Lardeaux, J.-M., Edel, J.-B., Štípská, P. \& Ulrich, S. (2009). An Andean type Palaeozoic convergence in the Bohemian Massif. Comptes Rendus Geoscience 341, 266-286.

Schumacher M.E., 2002. Upper Rhine Graben: Role of preexisting structures during rift evolution. Tectonics 21, $\mathrm{n}^{\circ}$ 1. doi: 10.1029/2001TC900022.

Siat, A., 1954. Observations pétrographiques sur les sables argileux blancs de DambachEpfig. Bulletin du Service de la Carte Géologique d'Alsace Lorraine 7, 81-84.

Sissingh, W., 2001. Tectonostratigraphy of the West Alpine Foreland: correlation of Tertiary sedimentary sequences, changes in eustatic sea-level and stress regimes. Tectonophysics, 333, 361-400. 
Skrzypek, E., 2011. Contribution structural, pétrologique et géochronologique à la tectonique intracontinentale de la chaîne hercynienne d'Europe (Sudètes, Vosges). Strasbourg University Phd thesis, $416 \mathrm{p}$.

Skrzypek, E., Schulmann K., Tabaud A.S., Edel J.B., 2014. Palaeozoic evolution of the Variscan Vosges Mountains. In: Schulmann K., Martinez Catalan J.R., Lardeaux J.M., Janousěk V., Oggiano G. (eds) 2014. The Variscan Orogeny: Extent, Timescale and the Formation of the European Crust. Geological Society, London, Special Publications, 405, 7 44. doi:10.1144/SP405.8.

Sittler, C., 1965. Le Paléogene des fossés rhénan et rhodanien: Etudes sédimentologiques et paléoclimatiques, Mém. Serv. Carte Géol. Alsace Lorraine, 24, 329, p. 1965.

Slightam., C., 2014. Characterizing seismic-scale faults pre-and post-drilling; Lewisian Basement, West of Shetlands, UK. In Advances in the Study of Fractured Reservoirs, edited by G. H. Spence, J. Redfern, R. Aguilera, T. G. Bevan, J. W. Cosgrove, G. D. Couples and J.M. Daniel, Geological Society, London.

Stampfli, G.M., Borel, G.D., Marchant, R., Mosar, J., 2002. Western Alps geological constraints on western Tethyan reconstructions. Journal of Virtual Explorer 7, 75-104.

Tabaud, A.S., 2012. Le magmatisme des Vosges: conséquence des subductions paléozoïques, (datation, pétrologie, géochimie, ASM). Strasbourg university, Phd thesis, 227p.

Tabaud, A.S., Whitechurch, H., Rossi, P., Schulmann, K., Guerrot, C., Cocherie, A., 2014. Devonian-Permian magmatic pulses in the northern Vosges Mountains (NE France): result of continuous subduction of the Rhenohercynien Ocean and Avalonian passive margin. In: Schulmann K., Martinez Catalan J.R., Lardeaux J.M., Janousěk V., Oggiano G. (eds) 2014. The Variscan Orogeny: Extent, Timescale and the Formation of the European Crust. Geological Society, London, Special Publications, 405, 7-44.

Taktak, A.G., Lauer, J.P., 1972. Les apports de la géophysique à la connaissance des Vosges. Bull. Bulletin du Service de la Carte Géologique d'Alsace Lorraine 25, 21-25.

Terzaghi, R.D., 1965. Sources of errors in joint surveys. Geotechnique 15, 287-304.

Théobald, N., Ménillet, F., Vogt, H., Thévenin, A., Schwoerer, P., Lougnon, J., 1975. Carte géologique de Molsheim. BRGM geological map n²71, scale 1:50,000.

Tobschall, H.J., 1974. Geochemische Untersuchungen zum stofflichen Bestand und Sedimentationsmilieu pala ozoischer mariner Tone: Die Gehalte der Haupte- lemente und der Spurenelemente $\mathrm{Ni}, \mathrm{Cu}, \mathrm{Zn}, \mathrm{Rb}, \mathrm{Sr}, \mathrm{Y}, \mathrm{Zr}, \mathrm{Nb}$ und $\mathrm{Ba}$ in den Steiger Schiefern (Vogesen). $\mathrm{PhD}$ thesis, University of Mainz.

Trice, R., 2014. Basement exploration, West of Shtelands: progess in opening a new play on the UKCS. Geological Society, London, Special Publications, v. 397, 1, p. 81-105, doi:10.1144/SP397.3.

Van der Voo, R., 1993. Paleomagnetism of the Atlantic, Tethys and Iapetus oceans. Cambridge University press, Cambridge, 411p.

von Eller, J.P., Ménillet, F., Hollinger, J., Guillaume, C., Billoret, R., Fluck, P., Maïaux, C., 1975. Carte géologique de Saint-Dié. BRGM geological map n³06, scale 1:50,000. 
von Raumer, J.F., Stampfli, G.M., Bussy, F., 2003. Gondwana derived microcontinents the constituents of the Variscan and Alpine collisional orogens. Tectonophysics 365, p. 7-22.

Wang, X., 2005, Stereological interpretation of rock fracture traces on borehole walls and other cylindrical surfaces. PhD thesis, Blacksburg, Virginia, Virginia Polytechnic Institute and State University, $113 \mathrm{p}$.

Walter, R., 1995. Geologie von Mitteleuropa. Schweizerbart, Stuttgart, Germany, 566 p.

Yielding, G., Walsh, J., Watterson, J., 1992. The prediction of small-scale faulting in reservoirs. First Break 10, 12.

Ziegler P. A., European Cenozoic rift system. Tectonophysics 208, p. 91-111.

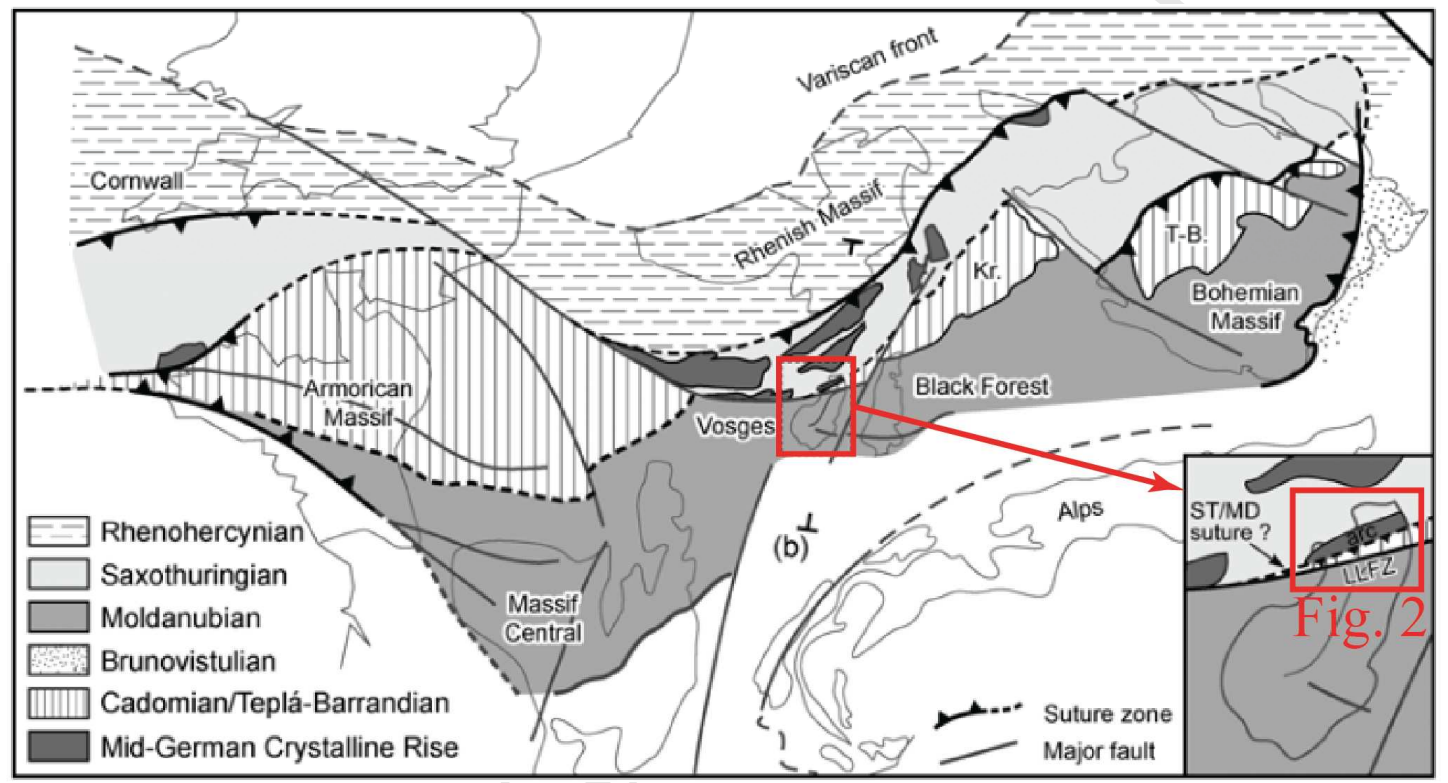

Figure 1: Map of the lithotectonic domains of the Hercynien orogeny in Europe modified by Skrzypek et al. (2014) after Edel and Schulmann (2009), with the location of the area of interest (Fig. 2). 


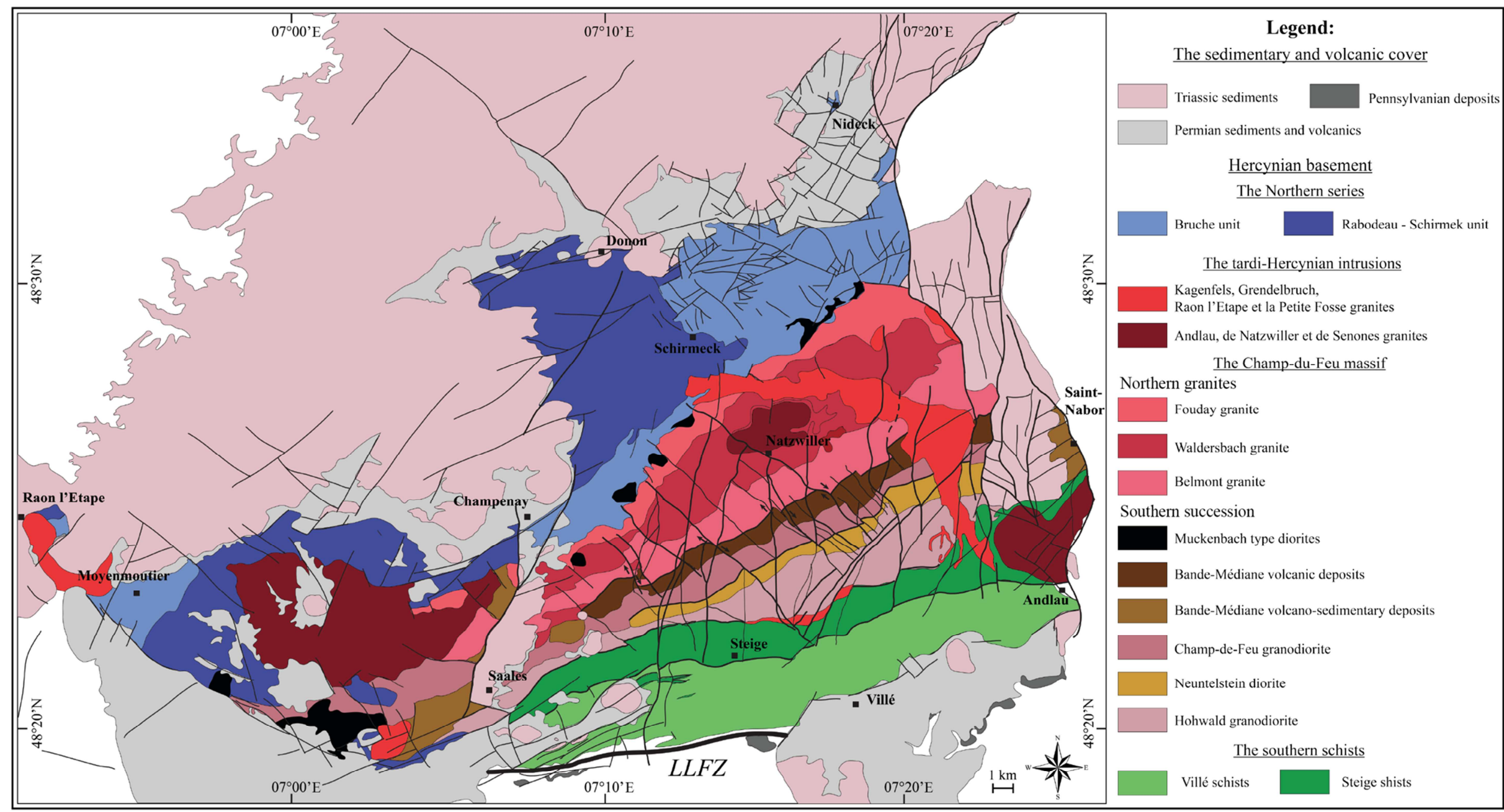

Figure 2: Simplified map of the Northern Vosges Mountains, redrawn after Blanalt et al. (1972), Théobalt et al. (1975), von Eller et al. (1975), Ménillet et al. (1978) and Elsass et al. (2008). 


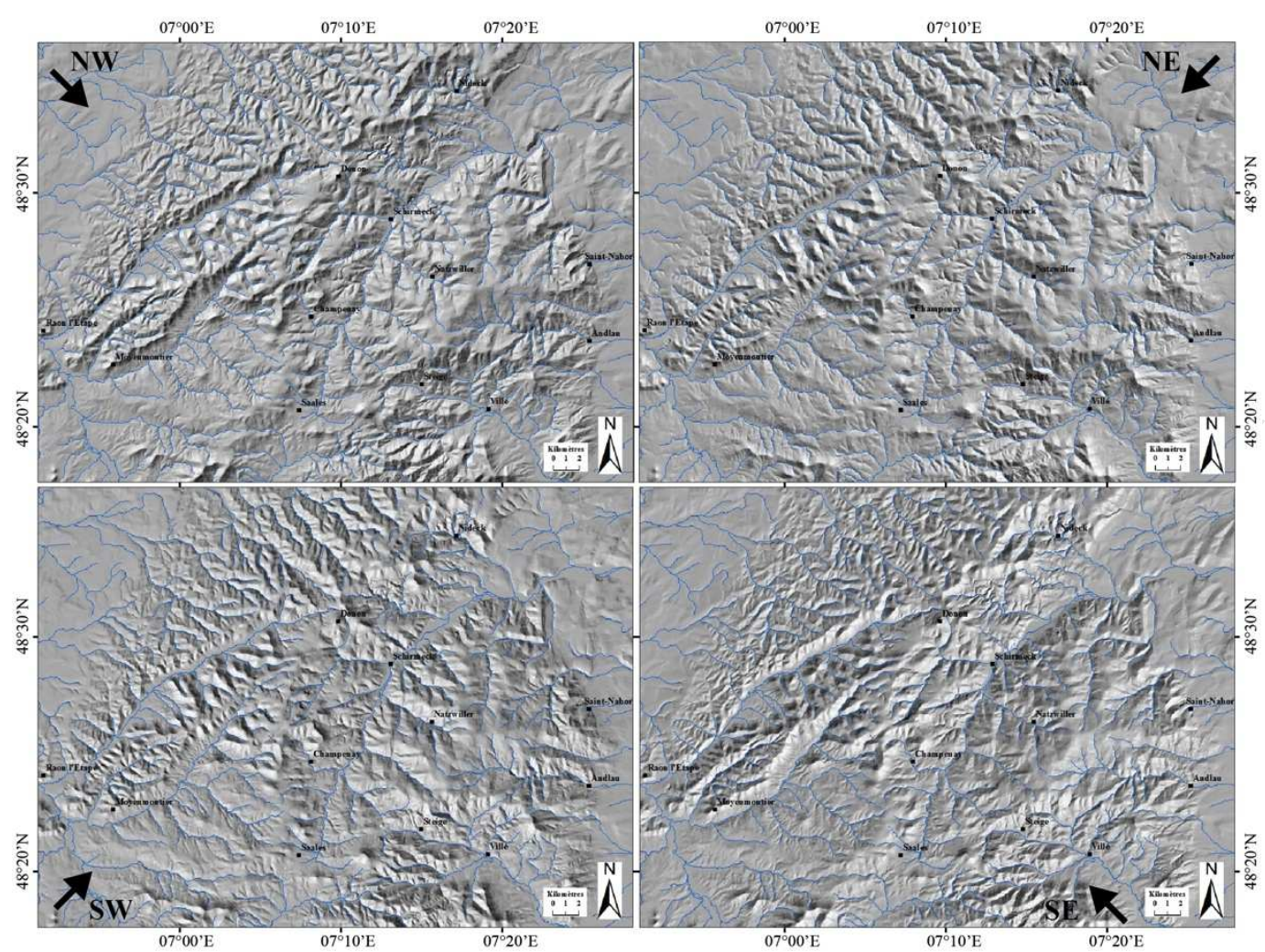

Figure 3: a) DTM data with hydrological network used for the lineament mapping (IGN, BD Alti ${ }^{\circledR}$ and $B D$ Carthage ${ }^{\circledR}, R G F 93$ referential) with the different modelled sunlight from $N W$, $N E, S W$ and $N E$ at an inclination of $45^{\circ}$.

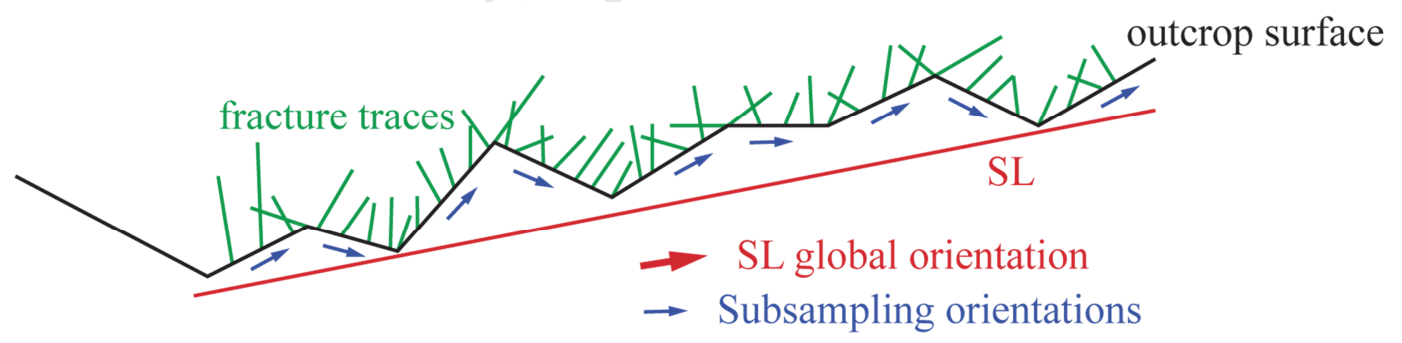

Figure 4: Schematic view of the orientation sampling bias on an SL measurement. 


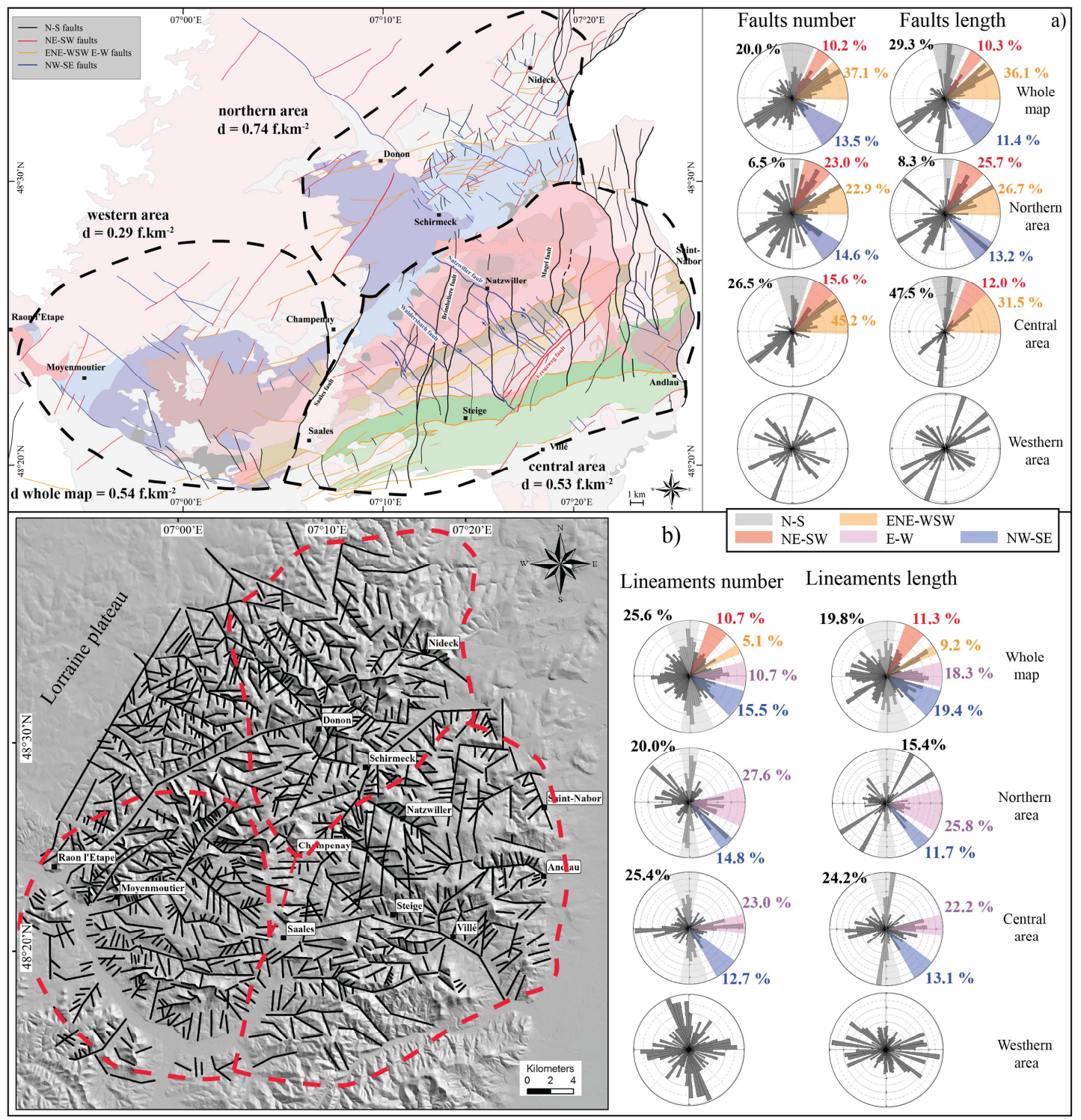

Figure 5: a) Map of faults combined from bibliographic data (Blanalt et al., 1972; Théobalt et al., 1975; von Eller et al., 1975; Ménillet et al., 1978; Elsass et al., 2008) classified by orientation and orientation plot (length weighted) associated with the faults, $b$ ) Traced lineament map on DTMs with NE lightning and orientation diagram in number and length. 


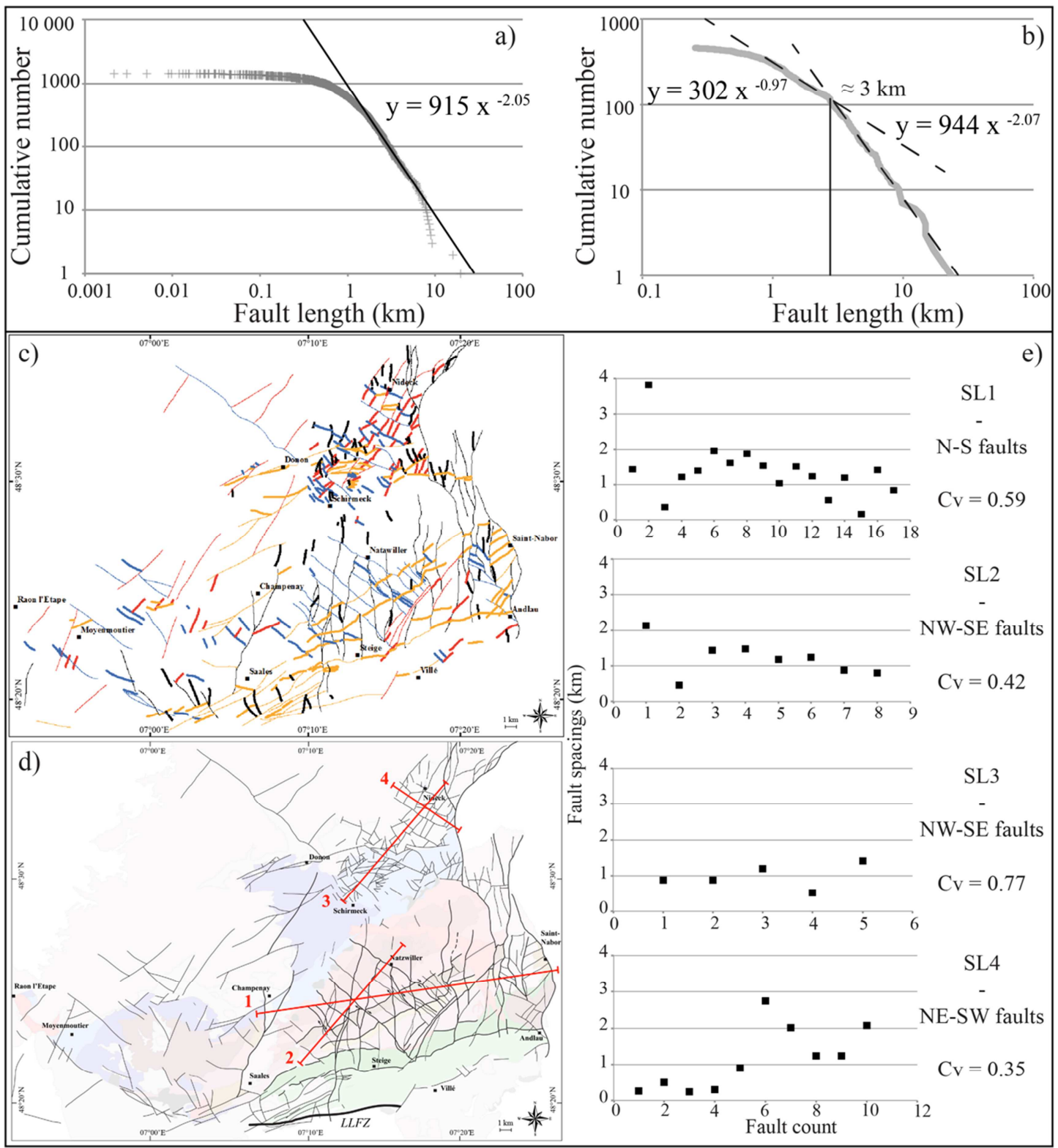

Figure 6: Length distribution of the faults on a) the DTMs map and b) the geological map, $c$ ) map the faults less than $3 \mathrm{~km}$ in length d) Map of the location of the different scan lines for spacing measuring of the faults, e) spacing results for each $S L$. 


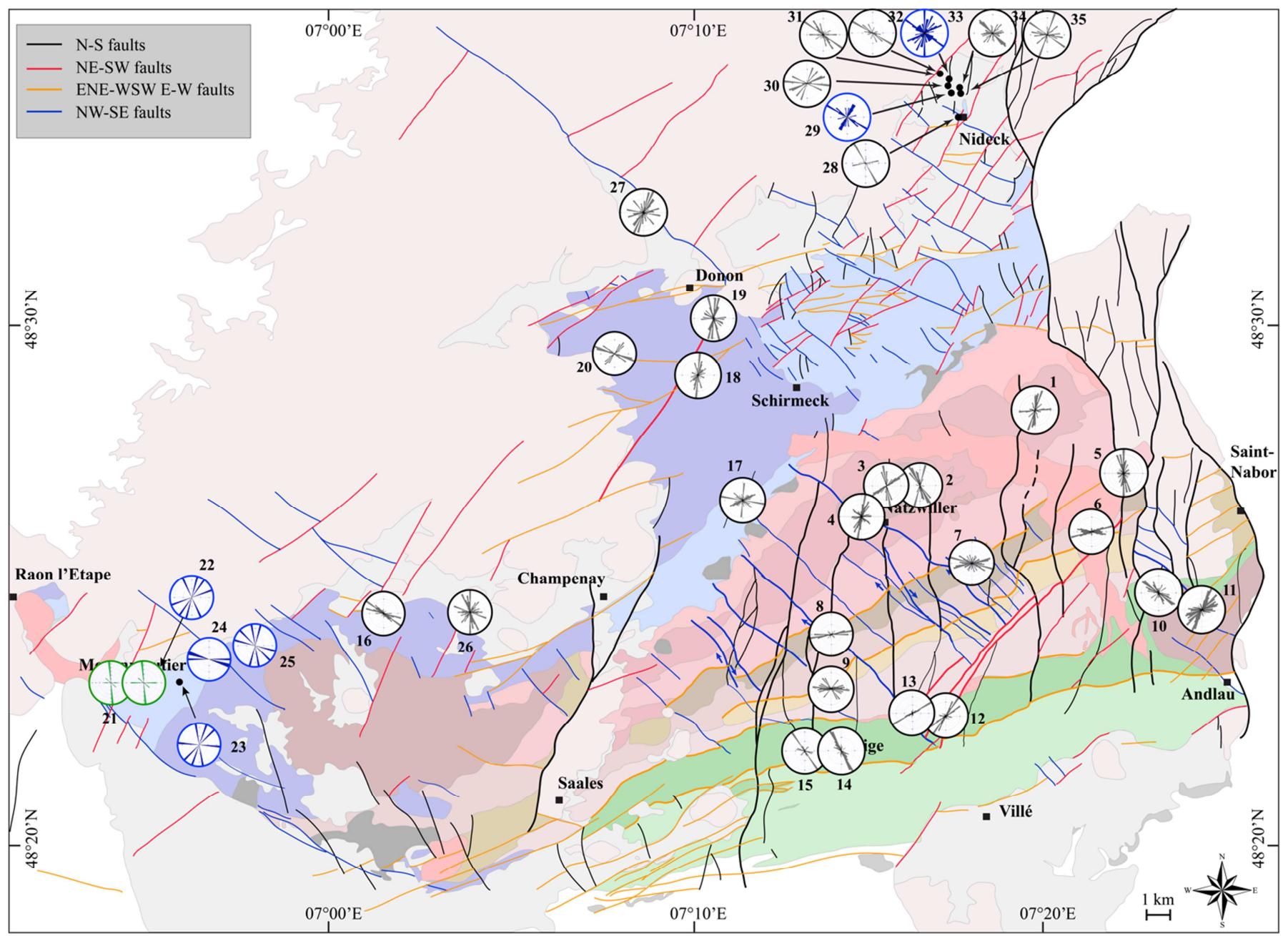

Figure 7: Structural map of the Northern Vosges with orientation diagrams of the different outcrops studied. Black lines represent outcrops where rigorous scan lines have been drawn. Data extracted from outcrop photographs is in green. Blue is used to show outcrops where only a few fractures could be measured regardless of the location method. 


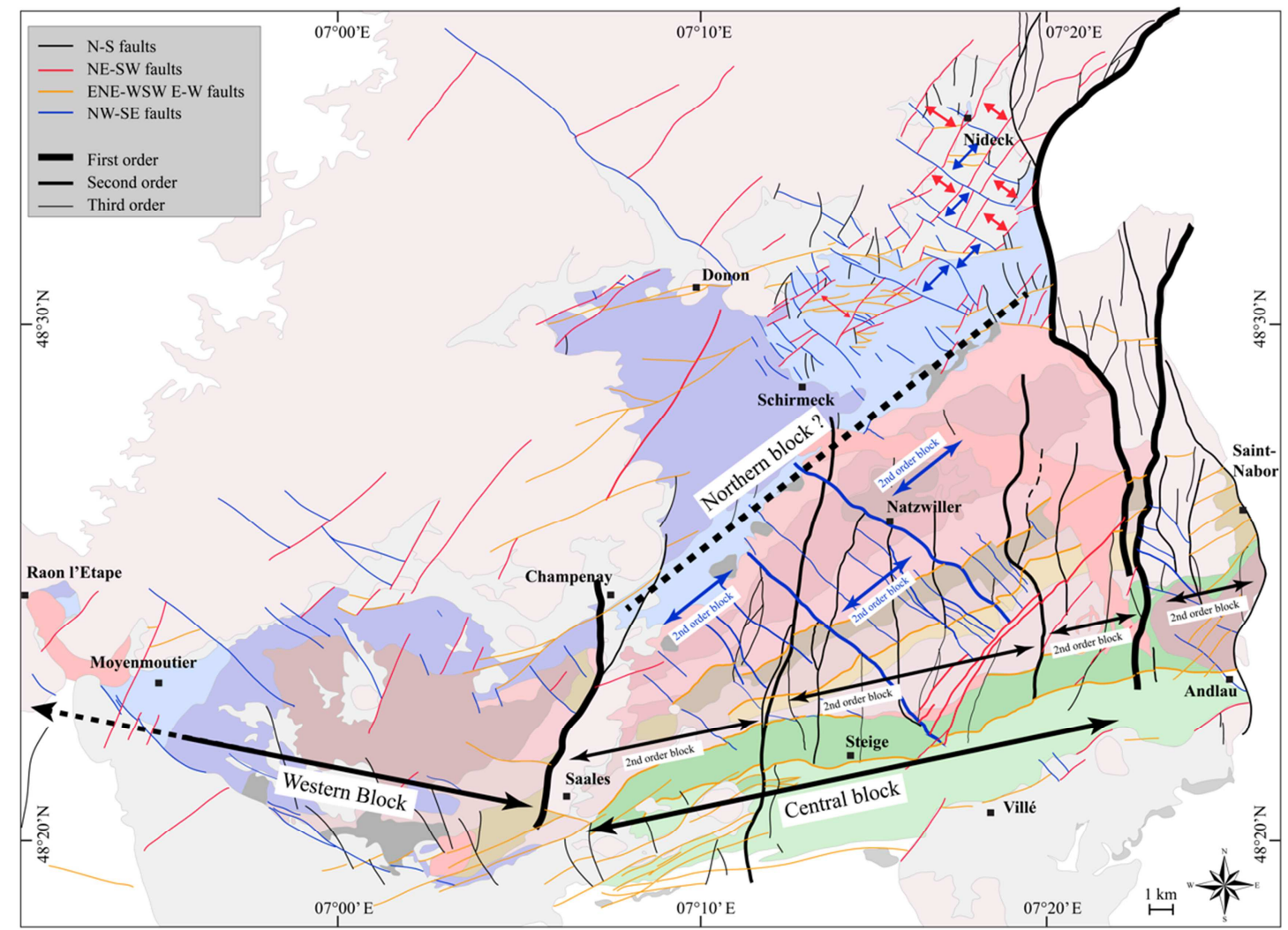

Figure 8: Classification of the faults and structural blocks in first, second and third-order in the studied in light of the geological, DTMs and fracture data. 
a)

URG cross-section
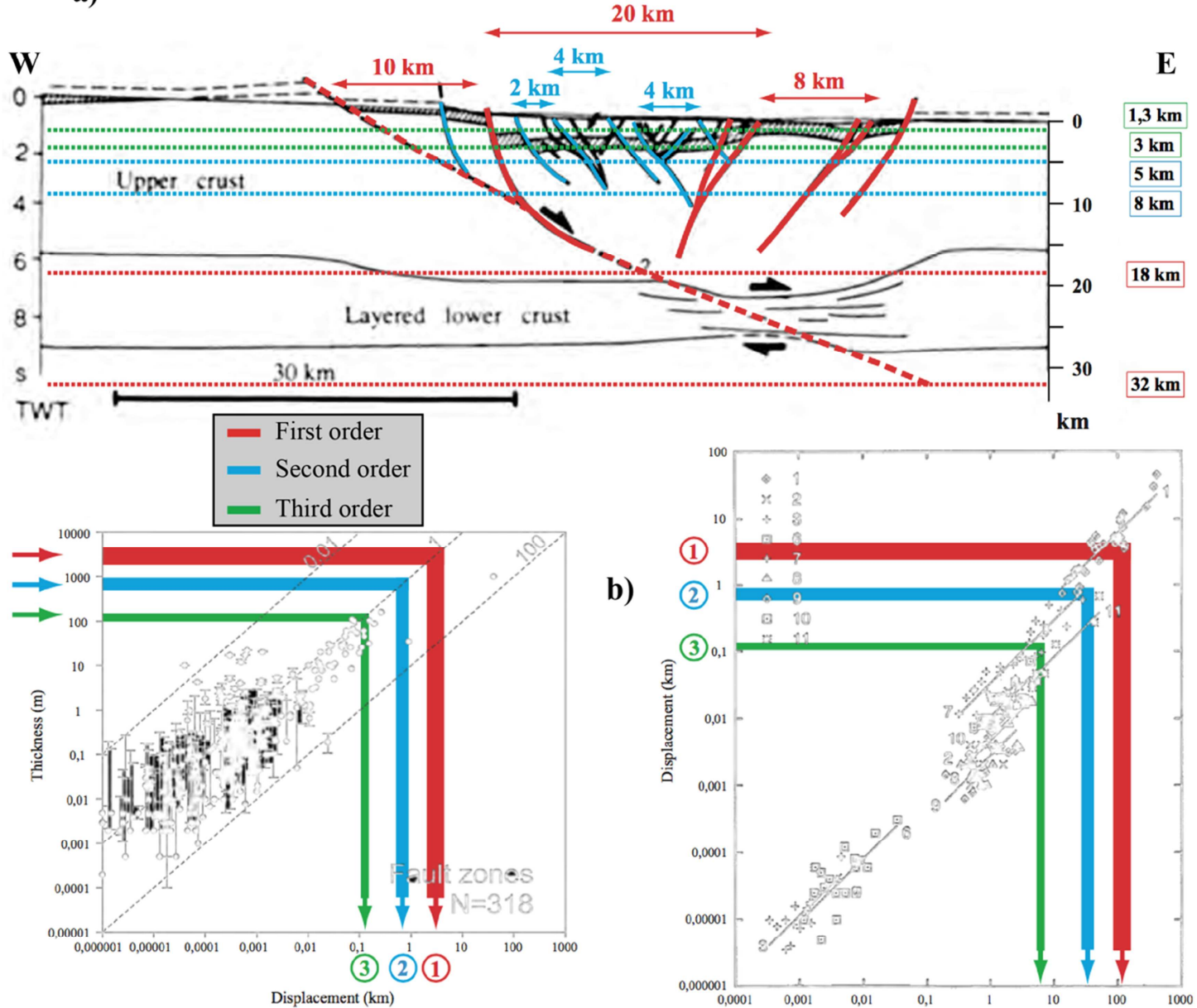

b)

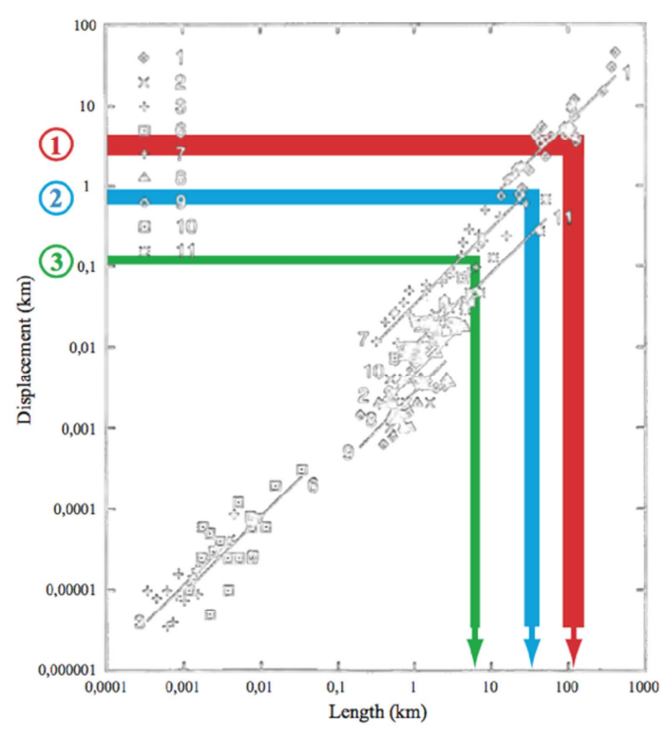

Figure 9: Schematic large-scale URG W-E cross-section with interpretation of the fault orders (Le Garzic, 2010), b) interpreted fault parameters relation thickness - displacement and displacement - length from bibliographic synthesis (Le Garzic, (2010) after Clark and Cox, (1996) and Childs et al., (2009). 


\begin{tabular}{|c|c|c|c|c|c|c|c|c|c|c|c|c|c|}
\hline Outcrop & Lithology & $\begin{array}{c}\text { Proximity to } \\
\text { fault }\end{array}$ & SL Orientation & $\begin{array}{l}\text { Length } \\
(\mathrm{m})\end{array}$ & $\begin{array}{c}\mathrm{Nb} \text { of } \\
\text { fractures }\end{array}$ & \begin{tabular}{|l|}
$\begin{array}{l}\text { Density } \\
\text { (frac/m) }\end{array}$ \\
\end{tabular} & Outcrop & Lithology & $\begin{array}{c}\text { Proximity to } \\
\text { fault }\end{array}$ & SL Orientation & $\begin{array}{c}\begin{array}{c}\text { Length } \\
(\mathrm{m})\end{array} \\
\end{array}$ & $\begin{array}{c}\mathrm{Nb} \text { of } \\
\text { fractures }\end{array}$ & $\begin{array}{l}\text { Density } \\
(\mathrm{frac} / \mathrm{m})\end{array}$ \\
\hline 1 & $\begin{array}{c}\text { Northern } \\
\text { granites }\end{array}$ & $\mathrm{N}-\mathrm{S}$ & $\mathrm{N} 130^{\circ} \mathrm{E}$ & 4.95 & 37 & 7.47 & 19 & $\begin{array}{l}\text { Schirmeck } \\
\text { volcanism }\end{array}$ & NE-SW & $\mathrm{N}^{2} 73^{\circ} \mathrm{E}$ & 5.50 & 75 & 13.64 \\
\hline 2 & $\begin{array}{l}\text { Younger } \\
\text { granites }\end{array}$ & $\mathrm{N}-\mathrm{S}$ & $\mathrm{N} 090^{\circ} \mathrm{E}$ & 9.10 & 73 & 8.02 & 20 & $\begin{array}{l}\text { Schirmeck } \\
\text { volcanism }\end{array}$ & ENE-WSW & $\mathrm{N} 040 / 130^{\circ} \mathrm{E}$ & 4.73 & 69 & 14.59 \\
\hline 3 & $\begin{array}{l}\text { Younger } \\
\text { granites }\end{array}$ & $\mathrm{N}-\mathrm{S}$ & $\mathrm{N} 100^{\circ} \mathrm{E}$ & 4.8 & 38 & 7.92 & 21a & Bruche unit & NE-SW & ${\mathrm{N} 070^{\circ}}^{\circ} \mathrm{E}$ & & 1392 & 24.05 \\
\hline 4 & $\begin{array}{l}\text { Younger } \\
\text { granites }\end{array}$ & NW-SE & $\mathbf{N 1 1 0}^{\circ} \mathrm{E}$ & 20.20 & 225 & 21.09 & $21 \mathrm{~b}$ & Bruche unit & NE-SW & ${\mathrm{N} 070^{\circ}}^{\circ} \mathrm{E}$ & & 557 & 21.06 \\
\hline 5 & $\begin{array}{l}\text { Younger } \\
\text { granites }\end{array}$ & $\begin{array}{l}\text { N-S, ENE- } \\
\text { WSW }\end{array}$ & $\mathrm{N} 092^{\circ} \mathrm{E}$ & 15.70 & 73 & 4.65 & 22 & Bruche unit & NE-SW & $\mathrm{X}$ & $\mathrm{X}$ & 4 & $\mathrm{X}$ \\
\hline 6 & $\begin{array}{l}\text { Younger } \\
\text { granites }\end{array}$ & $\begin{array}{l}\text { N-S, ENE- } \\
\text { WSW }\end{array}$ & $\mathrm{N} 140^{\circ} \mathrm{E}$ & 14.92 & 135 & 9.05 & 23 & Bruche unit & NW-SE & $\mathrm{X}$ & $X$ & 4 & $X$ \\
\hline 7 & $\begin{array}{l}\text { Bande- } \\
\text { Médiane }\end{array}$ & $\begin{array}{c}\text { NW-SE, ENE- } \\
\text { WSW }\end{array}$ & $\mathrm{N} 002 / 170^{\circ} \mathrm{E}$ & $3.43+1.6$ & $62+36$ & 19.48 & 24 & Bruche unit & NW-SE & $\mathrm{X}$ & $\mathrm{X}$ & 3 & $\mathrm{X}$ \\
\hline 8 & $\begin{array}{c}\text { Bande- } \\
\text { Médiane }\end{array}$ & NW-SE, N-S & $\mathbf{N 1 9 0}^{\circ} \mathrm{E}$ & 2.48 & $49+42$ & 36.64 & 25 & $\begin{array}{l}\text { Schirmeck } \\
\text { volcanism }\end{array}$ & NW-SE & $\mathrm{X}$ & $\mathrm{X}$ & 4 & $\mathrm{X}$ \\
\hline 9 & $\begin{array}{c}\text { Neuntelstein } \\
\text { diorite }\end{array}$ & $\mathrm{N}-\mathrm{S}$ & $\mathrm{N} 000^{\circ} \mathrm{E}$ & 2.87 & 67 & 23.34 & 26 & $\begin{array}{c}\text { Permian } \\
\text { sediments }\end{array}$ & NE-SW & Many directions & $\begin{array}{c}22.44 \mathrm{au} \\
\text { total }\end{array}$ & 148 & 6,60 \\
\hline 10 & $\begin{array}{l}\text { Steige } \\
\text { schists }\end{array}$ & NW-SE & $\mathrm{N} 218.15^{\circ} \mathrm{E}$ & 5.85 & 86 & 14.70 & 27 & $\begin{array}{c}\text { Permian } \\
\text { volcanism }\end{array}$ & NW-SE & $\mathrm{N} 128^{\circ} \mathrm{E}$ & 7.50 & 82 & 10.93 \\
\hline 11 & $\begin{array}{l}\text { Younger } \\
\text { granites }\end{array}$ & $\begin{array}{c}\text { N-S, NW-SE, } \\
\text { NE-SW }\end{array}$ & $\mathrm{N} 145.10^{\circ} \mathrm{E}$ & 16.22 & 140 & 8.63 & 28 & Bruche unit & $\begin{array}{c}\text { NE-SW, NW- } \\
\text { SE }\end{array}$ & $\mathrm{N} 060^{\circ} \mathrm{E}$ & 3.34 & 58 & 17.37 \\
\hline 12 & $\begin{array}{l}\text { Younger } \\
\text { granites }\end{array}$ & NE-SW & $\mathbf{N} 150 / 155^{\circ} \mathrm{E}$ & $1.69+3$ & $70+59$ & 27.50 & 29 & $\begin{array}{c}\text { Permian } \\
\text { volcanism }\end{array}$ & $\mathrm{N}-\mathrm{S}$ & $\mathrm{X}$ & $\mathrm{X}$ & 35 & $\mathrm{X}$ \\
\hline 13 & Granodiorite & $\begin{array}{l}\text { NE-SW, ENE- } \\
\text { WSW }\end{array}$ & $\mathrm{N} 150^{\circ} \mathrm{E}$ & 13.76 & 180 & 13.08 & 30 & $\begin{array}{c}\text { Permian } \\
\text { volcanism }\end{array}$ & N-S & $\mathrm{N} 178^{\circ} \mathrm{E}$ & 5.82 & 59 & 10.14 \\
\hline 14 & $\begin{array}{l}\text { Steige } \\
\text { schists }\end{array}$ & N-S & $\mathrm{N} 034 / 030^{\circ} \mathrm{E}$ & $4.9+4.6$ & $45+24$ & \begin{tabular}{|l|}
7.26 \\
\end{tabular} & 31 & $\begin{array}{c}\text { Permian } \\
\text { volcanism }\end{array}$ & NW-SE & $\mathrm{N} 057 / 048 / 028^{\circ} \mathrm{E}$ & 13.10 & 110 & 8.40 \\
\hline 15 & $\begin{array}{l}\text { Steige } \\
\text { schists }\end{array}$ & $\mathrm{N}-\mathrm{S}$ & $\mathrm{N} 078^{\circ} \mathrm{E}$ & 7.98 & 75 & 9.40 & 32 & $\begin{array}{c}\text { Permian } \\
\text { sediments }\end{array}$ & NW-SE & $\mathrm{N} 028 / 060 / 048^{\circ} \mathrm{E}$ & 8.34 & 62 & 7.43 \\
\hline 16 & $\begin{array}{l}\text { Schirmeck } \\
\text { volcanism }\end{array}$ & NE-SW & $\mathrm{N} 007^{\circ} \mathrm{E}$ & 9.23 & 132 & 14.30 & 33 & $\begin{array}{c}\text { Permian } \\
\text { volcanism }\end{array}$ & $\mathrm{N}-\mathrm{S}$ & $\mathrm{X}$ & $\mathrm{X}$ & 64 & $\mathrm{X}$ \\
\hline 17 & $\begin{array}{l}\text { Schirmeck } \\
\text { volcanism }\end{array}$ & NW-SE & $\mathrm{N} 032^{\circ} \mathrm{E}$ & 3.98 & 94 & 23.62 & 34 & $\begin{array}{c}\text { Permian } \\
\text { volcanism }\end{array}$ & $\mathrm{N}-\mathrm{S}$ & $\mathrm{N} 090^{\circ} \mathrm{E}$ & 7.5 & 80 & 10.67 \\
\hline 18 & $\begin{array}{l}\text { Schirmeck } \\
\text { volcanism }\end{array}$ & ENE-WSW & $\begin{array}{c}\mathrm{N} 107.15 / 082.07 \\
/ 125^{\circ} \mathrm{E} \\
\end{array}$ & $\begin{array}{c}2.56+2.65 \\
+2.06\end{array}$ & $29+16+31$ & 10.45 & 35 & $\begin{array}{c}\text { Permian } \\
\text { volcanism }\end{array}$ & $\mathrm{N}-\mathrm{S}$ & $\mathrm{N} 000 / 115^{\circ} \mathrm{E}$ & 10.8 & 123 & 11.39 \\
\hline
\end{tabular}

Table 1: Characteristics of the fractures measured on each outcrop studied: in black rigorous scan lines have been drawn, indicated by the length and the orientation of the measurement line (when several values were observed: a series of small SL with different orientation), data shown in green is extracted from outcrop photographs, indicated by the dimension and orientation of the associated fracture map, blue represents outcrops where only few fractures could be measured regardless of location method, SL4, 8, 12 and 21 are located near the main fault core, as the others are in the fractured damages zones. 
Highlights :

- Analysis of outcropping analogues of fractured basement rocks reservoirs has been done.

- Geological data, DTM interpretation and fracture analysis on outcrop are combined.

- A fault organization in three orders of scale with characteristic fault parameters can be indentified.

- The three-orders spatial arrangement is comparable to other rift-related basin basements.

- Petrographical variation of the basement rock led to change in the fracture network. 